\title{
Prognostic Significance of LncRNA PVT1 and Its Potential Target Gene Network in Human Cancers: a Comprehensive Inquiry Based Upon 21 Cancer Types and 9972 Cases
}

\author{
Rong-quan He $\mathrm{Mei}^{\mathrm{a}}$-jiao Qin ${ }^{\mathrm{a}}$ Peng Lin ${ }^{\mathrm{b}}$ Yi-Huan Luo ${ }^{c}$ Jie Ma $\mathrm{H}^{\mathrm{a}}$ Hong Yang ${ }^{\mathrm{b}}$ \\ Xiao-hua $\mathrm{Hu}^{\mathrm{a}}$ Gang Chen ${ }^{\mathrm{d}}$ \\ aDepartment of Medical Oncology, the First Affiliated Hospital of Guangxi Medical University, Nanning, \\ 'Department of Medical Ultrasonography, the First Affiliated Hospital of Guangxi Medical University, \\ Nanning, 'Department of Gastrointestinal Surgery, the First Affiliated Hospital of Guangxi Medical \\ University, Nanning, dDepartment of Pathology, the First Affiliated Hospital of Guangxi Medical \\ University, Nanning, China
}

Key Words

Pvt1 • Cancer • Prognosis • Pathway • LncRNA

\begin{abstract}
Background/Aims: Whether the level of long noncoding RNA plasmacytoma variant translocation 1 gene (IncRNA PVT1) expression influences the clinical development and outcome of human cancers has not been thoroughly elucidated to date. Inconsistencies still exist regarding the associations between PVT1 and the clinicopathological features, including patient survival data. Additionally, the regulatory mechanism of PVT1 among human cancers remains unclear. Methods: we conducted a comprehensive inquiry to verify the implication of PVT1 expression in cancer patients by conducting a meta-analysis of 19 selected studies and The Cancer Genome Atlas (TCGA) database to examine the relationship between PVT1 expression and both the prognosis and clinicopathological features of cancer patients using STATA 12.0. In addition, Gene Ontology (GO) and Kyoto Encyclopedia of Genes and Genomes (KEGG) pathway enrichment analyses of the potential mRNA target genes of PVT1 gathered from TANRIC and Multi Experiment Matrix (MEM) were performed. Results: The level of PVT1 expression in tumor tissues was higher than in paired non-cancer tissues and was significantly associated with a poorer prognosis in cancer patients. Additionally, overexpression of PVT1 was significantly correlated with histological differentiation, tumor $(T)$ classification, lymph node $(\mathrm{N})$ classification and TNM stages. Furthermore, a total of 462 validated target genes were identified, and the GO and KEGG analyses demonstrated that the validated targets of
\end{abstract}


PVT1 were significantly enriched in several pathways, including the GnRH signaling pathway, the Cytokine-cytokine receptor interaction pathway, the Inflammatory mediator regulation of TRP channels pathway, and the Neuroactive ligand-receptor interaction pathway. Conclusion: PVT1 may serve as a potential biomarker associated with the progression and prognosis of human cancers.

(C) 2018 The Author(s)

Published by S. Karger AG, Basel

\section{Introduction}

As the technology of RNA deep sequencing (RNA-seq) is being widely used, there is a deeper appreciation for the transcriptome of organisms. According to the differences in length, non-coding RNA (ncRNA) can commonly be classified into two categories: transcripts less than 200 nucleotides are usually accepted as short/small RNAs including miRNAS, siRNAS, piRNAs and those longer than 200 nucleotides are classified as long non-coding RNAs (lncRNAs) [1]. ncRNA, a class of RNA that does not encode proteins, was thought to be transcription noise or evolutionary junk in the past $[2,3]$. However, multiple evidence have suggested that ncRNAs played important roles in a variety of biological processes. LncRNAs act as a regulator of gene expression and are closely associated with the development of many diseases, especially malignant tumors [4-7].

The human Plasmacytoma variant translocation 1 gene (PVT1) is an RNA gene homologous to the mouse PVT1 to the lncRNA class. This gene locus was first discovered in mouse plasma in the 1980s, and the strongest evidence for frequent variant translocation was found in plasmacytoma $[8,9]$. Around the same time, studies showed that the PVT1 gene locus also underwent a variant translocation in human Burkitt's lymphomas $[10,11]$. The PVT1 gene is located on chromosome 8, a recognized cancer risk locus shared with the well-known MYC oncogene_ENREF_12, suggesting that PVT1 is a potential oncogene [12]. In vitro experiments have demonstrated that PVT1 could promote proliferation, migration and invasion of cancer cells. Studies also observed that the level of PVT1 expression was higher in tumor tissues than in adjacent non-cancerous tissues and correlated with a poor prognosis $[13,14]$.

The evidence above revealed that PVT1 was involved in tumor progression. In addition, a previous meta-analysis had shown that the overexpression of PVT1 was significantly correlated with the prognosis and lymph node metastasis of cancers [15]. However, the sample size was limited, and the association of PVT1 with other clinicopathological parameters was not investigated in the study. Accordingly, we reviewed the pertinent literature and searched The Cancer Genome Atlas (TCGA) database to conduct the current study to exploring the clinicopathological and prognostic value of PVT1 in patients with various types of cancer. We also investigated the potential target genes of PVT1 through Gene Ontology (G0) and Kyoto Encyclopedia of Genes and Genomes (KEGG) analyses, and the possible mechanisms of action of PVT1 in tumor progression are discussed in this article.

\section{Materials and Methods}

Meta-analysis

Literature review and selection

We conducted a search of the English and Chinese medical literature in PubMed, ISI Web of Science, EMBASE, Science Direct, Wiley Online Library, WanFang, China National Knowledge Infrastructure (CNKI), and Chinese VIP to identify all publications related to PVT1 in cancer patients. Based on the purpose of the study, the search strategy combined the terms "long non-coding RNA PVT1" OR "PVT1" OR "plasmacytoma variant translocation." We also checked for related comments and references by other means. The closing date of our search was July 4, 2017.

The studies eligible for our meta-analysis were evaluated by two independent investigators (RQ He and MJ Qin) with the same multi-step process. Initially, the titles and abstracts were read to exclude the KARGER 


\section{Cellular Physiology Cell Physiol Biochem 2018;46:591-608 \begin{tabular}{l|l|l} 
and Biochemistry 10.1159/000488627 & $\begin{array}{l}\text { D } 2018 \text { The Author(s). Published by S. Karger AG, Basel } \\
\text { www.karger.com/cpb }\end{array}$
\end{tabular}}

He et al.: Prognostic Significance of PVT1 and Target Gene Network in Cancers

ineligible studies, which were either irrelevant, duplicate texts, reviews or case reports. Next, the full-text of the remaining studies were further checked by the same investigators individually. Finally, any disputes were addressed by a third reviewer (G Chen). Studies were considered eligible if they met the following inclusion criteria: (i) The clinical samples were gathered from tumor tissues; (ii) The correlation between PVT1 and survival data was studied and the PVT1 levels were measured by quantitative real-time PCR (qRTPCR); and (iii) The studies should provide sufficient data to determine the hazard ratios (HRs) value and its $95 \%$ confidence interval $(95 \% \mathrm{CI})$. The exclusion criteria were as follows: (i) Duplicated studies; (ii) Studies with insufficient data to calculate the HR value; (iii) Studies of animals or cell lines; and (iv) Reviews, letters, case reports and conference articles. If the survival analysis showed in the article were insufficient to calculate the HR value, we attempted to contact the author to obtain the original survival data.

\section{Data extraction}

The following key information was extracted from all eligible studies: the first author's name, publication year, cancer type, country, sample size, assay method, the criterion for dividing PVT1 into high and low groups, follow-up times, prognostic data, histological differentiation, tumor (T) classification, lymph node (N) classification, metastasis (M) classification and TNM stages. Engauge Digitizer 4.1 (http:// digitizer.sourceforge.net/) and Jayne F Tierney's publication [16] were used to extract the HR and 95\% CI indirectly from Kaplan-Meier survival curves if the articles did not provide complete survival data.

\section{Quality assessment}

The Newcastle-Ottawa Scale (NOS) [17] was used to evaluate the methodological quality of the selected studies by two investigators (RQ He and MJ Qin) independently. Each study was scored based on the following three part system: (i) selection, 0-4; (ii) comparability section, 0-2; and (iii) outcome section, 0-3. The score was no more than 9 points in total, and a score $\geq 6$ indicated the good quality of the study.

\section{Statistical analysis}

The information extracted from eligible studies was analyzed with STATA 12.0 software. The survival data were evaluated by HR and 95\%CI; PVT1 overexpression pointed to a poor prognosis if a pooled HR>1 was detected. The odd ratio (OR) and $95 \% \mathrm{CI}$ were calculated to analyze the association of human cancer with the clinicopathological parameters, which included gender, histological differentiation, tumor (T) classification, lymph node (N) classification, metastasis (M) classification and TNM stages. In addition, we performed subgroup analysis based upon the tumor types and the sources of overall survival data. Cochran's $\mathrm{Q}$ test and the $\mathrm{I}^{2}$ index were used to estimate the potential heterogeneity among the selected studies, $\mathrm{P}<0.05$ or $\mathrm{I}^{2}>50 \%$ were considered statistically significant. If there was no significant heterogeneity $(\mathrm{P}>0.05), \mathrm{a}$ fixed-effect model was used to calculate the HR values; otherwise, a random-effect model would be adopted. Finally, Begg's test was applied to evaluate the publication bias (a two-sided $\mathrm{P}<0.05$ was considered to be statistically significant).

\section{Analysis of the level of PVT1 expression in all cancers based upon TCGA data}

The level of PVT1 expression and overall survival data in the TCGA database were extracted from the Oncolnc website (http://www.oncolnc.org/) [18]. The experimental data were divided into two groups of high and low median level of PVT1 expression. The Cox proportional hazards model of SPSS 22.0 was used to estimate the influence of PVT1 overexpression on survival. We also obtained the level of PVT1 expression across all tumor samples and paired adjacent normal tissues from FireBrowse (http://firebrowse.org/) and GEPIA (http://gepia.cancerpku.cn/), an interactive web based TCGA database. Bar diagrams of PVT1 expression in cancers were plotted with Microsoft Excel 2003.

\section{GO and KEGG Pathway analysis of the validated target genes of PVT1}

We used TANRIC (http://ibl.mdanderson.org/tanric/_design/basic/index.html) [19] based upon the TCGAdatasetand MultiExperiment Matrix (http://biit.cs.ut.ee/mem/) based upon the ArrayExpressdatabase (http://www.ebi.ac.uk/arrayexpress/) to determine the potential targets of PVT1 in human cancers. VENNY diagram (https://omictools.com/venny-tool) was used to identify those genesoverlapping the two online platforms. To confirm the most significant processes and signaling pathways of PVT1 in human cancers, Gene ontology (GO) [20]_ enrichment analysis was conducted with DAVID Bioinformatics Resources 6.8 
(https://david.ncifcrf.gov/), and visualized with $\mathrm{R}$ version 3.3.3. The pathway enrichment analysis was carried out with Kyoto Encyclopedia of Genes and Genomes (KEGG) [21] _ENREF_21 data, which were obtained from DAVID Bioinformatics Resources 6.8 . The network of PVT1 and their related genes were visualized using the Cytoscape 3.5.1 software with the Bingo plug-in.

\section{Results}

Meta-analysis

Literature selection and summary of the study

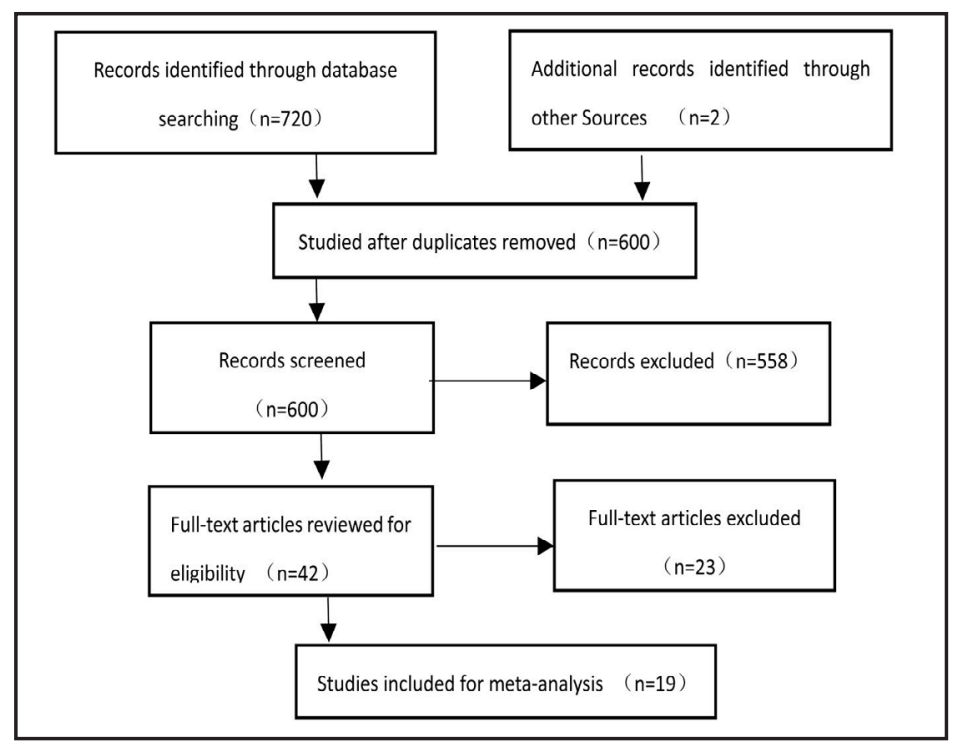

Fig. 1. Flow diagram of the search and selection of study patients. characteristics

We conducted a search published studies of the association of PVT1 expression and prognosis of cancer patients (Fig. 1). A total of 722 potential studies were identified after the primary search, of which 42 studies were considered eligible after title and abstract screening. Next, we examined the full text of the remaining articles. Ultimately, 19 studies $(n=2006)$ were included in our analysis and the main characteristics are shown in Table 1. The follow-up times ranged between 30 and 147.6 months. All selected studies investigated the association of PVT1 and survival analysis, including overall survival (OS), disease-specific survival (DSS), disease-free survival (DFS), relapse-free survival (RFS) or progressionfree survival (PFS); 8 studies explored the association between PVT1 and histological differentiation, 14 for TNM stage, 5 for T classification, 11 for $\mathrm{N}$ stage, 7 for M classification and 15 for Gender (shown in Table 2).

Correlation of IncRNA PVT1 with the clinicopathological characteristics of the study patients

As shown in Table 2, we discovered that high PVT1 level was remarkably related to histological differentiation (OR $=1.63,95 \% \mathrm{CI}: 1.21-2.19, \mathrm{P}=0.001 ; \mathrm{I} 2=37.6 \%$, and $\mathrm{P}=0.129$ ) (Fig. $5 \mathrm{~A}$ ), TNM stages (OR $=2.76,95 \% \mathrm{CI}: 2.18-3.50, \mathrm{P}<0.01$; $\mathrm{I} 2=41.2 \%$, and $\mathrm{P}=0.054$ ) (Fig. 5B), T stages (OR $=5.08,95 \% \mathrm{CI}$ : 2.30-11.22, $\mathrm{P}<0.01$; $\mathrm{I} 2=69.3$, and $\mathrm{P}=0.011$ ) (Fig. $5 \mathrm{C}$ ), positive lymph node metastasis (OR $=2.14,95 \% \mathrm{CI}: 1.18-3.91, \mathrm{P}=0.013$; $\mathrm{I} 2=77.1 \%$ and $\mathrm{P}<0.01$ ) (Fig. 6A). However, no significant association was found for distant metastasis (OR $=2.43$, 95\%CI: 0.96-6.14, $\mathrm{P}=0.061 ; \mathrm{I} 2=54 \%$, and $\mathrm{P}=0.042$ ) (Fig. $6 \mathrm{~B})$ and gender $(\mathrm{OR}=1.06$, 95\%CI: 0.84-1.34, $\mathrm{P}=0.611 ; \mathrm{I} 2=0.0 \%, \mathrm{P}=0.833$ ) (Fig. 6C). The above results indicated that tumors with high PVT1 levels appeared to exhibit aggressive biological behavior.

\section{Correlation of IncRNA PVT1 expression and survival}

We performed an analysis of the association of PVT1 expression and OS based upon the outcomes of the 19 selected studies and TCGA database, which revealed that overexpression of PVT1 was significantly associated with a poor prognosis. A random-effect model was chosen to combine the HR due to high heterogeneity ( $\mathrm{I} 2=62.5 \%, \mathrm{P}=0.00$ ), the HR for OS was 1.31 (95\% CI: 1.19-1.43, P<0.01) (Fig. 2). The pooled HR for DFS and RFS were 1.78 (95\% CI: 1.45-2.17, $\mathrm{P}<0.01$, fixed-effect model) with low heterogeneity (I2 $=0.0 \%, \mathrm{P}=0.755$ ) and 1.90 (95\% CI: 1.31-2.75, $\mathrm{P}<0.01$, fixed-effect model) with low heterogeneity (I2 $=0.0 \%$, $\mathrm{P}=0.379$ ), respectively (Fig. 4). 
Table 1. Main characteristics of the selected studies. N (M/F): number (male/female); HR: hazard ratio; CI: confidence interval; GC: gastric carcinoma; OS: osteosarcoma; ESCC: esophageal squamous cell carcinoma; SCLC: small cell lung cancer; OC: ovarian cancer; CC: cervical cancer; NSCLC: non-small cell lung cancer; PDAC: pancreatic (ductal) adenocarcinoma; HCC: hepatocellular carcinoma; CRC: colon rectal carcinoma; OS: overall survival; DSS: disease-specific survival; DFS: disease-free survival; RFS: relapse-free survival; PFS: progression-free survival; NR: not report; *: approximate times extracted form survival curve

\begin{tabular}{|c|c|c|c|c|c|c|c|c|c|}
\hline $\begin{array}{l}\text { First } \\
\text { author }\end{array}$ & Year & Country & $\begin{array}{c}\text { Cancer } \\
\text { types }\end{array}$ & $N(M / F)$ & High expression & $\begin{array}{l}\text { Follow- } \\
\text { up } \\
\text { (Months) }\end{array}$ & Outcome & HR $(95 \% \mathrm{CI})$ & $\begin{array}{l}\text { Quality } \\
\text { score }\end{array}$ \\
\hline Wu D [41] & 2017 & China & NSCLC & $31(22 / 9)$ & NR & $80^{*}$ & OS & $\begin{array}{l}2.67(0.87- \\
8.23)\end{array}$ & 8 \\
\hline Xu M [33] & 2017 & China & GC & 190 & by the mean value & 85 & $\begin{array}{l}\text { DFS } \\
\text { DSS }\end{array}$ & $\begin{array}{c}1.75(1.25- \\
2.56) \\
1.64(1.15- \\
2.39)\end{array}$ & 8 \\
\hline Song J [34] & 2017 & China & os & $46(27 / 19)$ & Median expression for PVT1 & $72^{*}$ & OS & $\begin{array}{c}2.43(1.22- \\
4.80) \\
2.75(1.35-\end{array}$ & 8 \\
\hline Li P [28] & 2017 & China & ESCC & $104(24 / 80)$ & median level of PVT1 & $90^{*}$ & $\begin{array}{c}\text { OS } \\
\text { DFS }\end{array}$ & $\begin{array}{c}5.59) \\
2.15(1.19- \\
3.89)\end{array}$ & 8 \\
\hline Li Q [39] & 2016 & China & CRC & $30(15 / 15)$ & NR & 30 & os & $\begin{array}{l}2.02(1.07- \\
3.83)\end{array}$ & 7 \\
\hline Huang C [27] & 2016 & China & SCLC & $120(74 / 46)$ & $\begin{array}{c}\text { median expression level of all } \\
\text { samples }\end{array}$ & $96^{*}$ & os & $\begin{array}{l}1.78(1.08- \\
2.94)\end{array}$ & 8 \\
\hline Zhou Q [32] & 2016 & China & OS & 53 & NR & $60^{*}$ & os & $\begin{array}{l}2.57(1.25- \\
5.27)\end{array}$ & 7 \\
\hline Liu Y [29] & 2016 & China & OC & $85(56 / 29)$ & $\geq$ median level 3.53 & $60^{*}$ & os & $\begin{array}{l}3.01(1.57- \\
6.67)\end{array}$ & 8 \\
\hline Iden M [13] & 2016 & $\begin{array}{l}\text { United } \\
\text { State }\end{array}$ & $\mathrm{CC}$ & 127 & Median PVT1 expression level & NR & os & $\begin{array}{l}2.02(1.07- \\
3.82)\end{array}$ & 7 \\
\hline Wan L [14] & 2016 & China & NSCLC & $100(62 / 43)$ & $\begin{array}{l}\text { Median expression ;fold- } \\
\text { change } \geq 3.0\end{array}$ & $36^{*}$ & $\begin{array}{c}\text { OS } \\
\text { PFS }\end{array}$ & $\begin{array}{c}2.40(1.21- \\
4.90) \\
2.51(1.58- \\
3.98)\end{array}$ & 8 \\
\hline Chen J [26] & 2016 & China & GC & $187(144 / 43)$ & NR & 85 & $\begin{array}{c}\text { OS } \\
\text { DFS }\end{array}$ & $\begin{array}{c}1.46(1.00- \\
2.11) \\
1.43(1.00- \\
2.06)\end{array}$ & 7 \\
\hline Huang C [54] & 2015 & China & PDAC & $85(56 / 29)$ & Expression ratio $\geq 3.53$ & $60^{*}$ & os & $\begin{array}{c}3.01(1.57- \\
6.67)\end{array}$ & 8 \\
\hline Yuan C [30] & 2015 & China & GC & $111(70 / 41)$ & median value 5.22 -fold & 48 & $\begin{array}{c}\text { OS } \\
\text { DFS }\end{array}$ & $\begin{array}{c}2.28(1.05- \\
4.93) \\
2.21(1.111- \\
4.39)\end{array}$ & 8 \\
\hline Cui D [55] & 2015 & China & NSCLC & $108(69 / 39)$ & $>$ Median level & $38^{*}$ & $\begin{array}{c}\text { OS } \\
\text { DFS }\end{array}$ & $\begin{array}{c}1.72(1.14- \\
3.25) \\
1.98(1.16- \\
4.35)\end{array}$ & 8 \\
\hline Ding C [56] & 2015 & China & HCC & $214(195 / 19)$ & Above the cut-off & 124 & $\begin{array}{c}\text { OS } \\
\text { RFS }\end{array}$ & $\begin{array}{c}1.21(0.73- \\
1.99) \\
1.65(1.02- \\
2.68)\end{array}$ & 8 \\
\hline Kong R [36] & 2015 & China & GC & $80(48 / 32)$ & Median expression for PVT1 & $38^{*}$ & $\begin{array}{c}\text { OS } \\
\text { DFS }\end{array}$ & $\begin{array}{c}2.03(1.07- \\
4.10) \\
2.22(1.13- \\
4.34)\end{array}$ & 8 \\
\hline $\begin{array}{l}\text { Takahashi Y } \\
{[22]}\end{array}$ & 2014 & Japan & CRC & $164(97 / 67)$ & Above the 20 percentile value & 147.6 & os & $\begin{array}{l}2.53(1.15- \\
10.75)\end{array}$ & 8 \\
\hline Yang Y [57] & 2014 & China & NSCLC & $82((49 / 33)$ & $\begin{array}{c}\text { \Median expression level for } \\
\text { PVT1 2.87) }\end{array}$ & $60^{*}$ & os & $\begin{array}{l}3.27(2.18- \\
6.94)\end{array}$ & 8 \\
\hline Wang F [23] & 2014 & China & $\mathrm{HCC}$ & $89(73 / 16)$ & Above the cut-off value & $50^{*}$ & $\begin{array}{c}\text { OS } \\
\text { RFS }\end{array}$ & $\begin{array}{c}2.44(1.23- \\
4.83) \\
2.32(1.30- \\
4.14)\end{array}$ & 8 \\
\hline
\end{tabular}

Table 2. Combinations of data evaluating the associations of PVT1 with the clinicopathological characteristics of the study patients

\begin{tabular}{|c|c|c|c|c|c|c|c|c|}
\hline \multirow{2}{*}{ Clinicopathological parameters } & \multirow{2}{*}{ Studies(n) } & \multirow{2}{*}{\multicolumn{2}{|c|}{$\begin{array}{c}\text { Test } \\
\text { Event } \\
\text { Total }\end{array}$}} & \multirow{2}{*}{\multicolumn{2}{|c|}{$\begin{array}{c}\text { Control } \\
\text { Event } \\
\text { Total }\end{array}$}} & \multirow{2}{*}{ model } & \multirow{2}{*}{ OR $(95 \% \mathrm{CI})$} & $\begin{array}{c}\text { Test for } \\
\text { heterogeneity }\end{array}$ \\
\hline & & & & & & & & \\
\hline $\begin{array}{l}\text { Histological differentiation (Poorly/Well- } \\
\text { Moderately) }\end{array}$ & $8(1050$ & 239 & 665 & 106 & 385 & Fixed & $1.63(1.21-2.19)$ & $37.6 \% \quad 0.129$ \\
\hline TNM state(III-IV/I-II) & $14(1439)$ & 539 & 889 & 197 & 550 & Fixed & $2.76(2.18-3.50)$ & $41.2 \% \quad 0.054$ \\
\hline T classification (T3-T4/T1-T2) & $5(469)$ & 174 & 282 & 47 & 187 & random & $\begin{array}{c}5.08(2.30- \\
11.22)\end{array}$ & $69.3 \% \quad 0.011$ \\
\hline $\mathrm{N}$ classification (N1-N3/N0) & $11(1158)$ & 435 & 718 & 196 & 440 & random & $2.14(1.18-3.91)$ & $77.1 \%<0.01$ \\
\hline M classification (M1/M0) & $7(855)$ & 69 & 518 & 18 & 337 & random & $2.43(0.96-6.14)$ & $54 \% \quad 0.042$ \\
\hline Gender(Male/Female) & 15(1552) & 645 & 976 & 356 & 576 & Fixed & $1.06(0.84-1.34)$ & $0.0 \% \quad 0.833$ \\
\hline
\end{tabular}


Fig. 2. Meta-analysis of the selected studies and TCGA data estimating the association of PVT1 with the patients' overall survival (OS) $(\mathrm{P}<0.01$, random effect model).

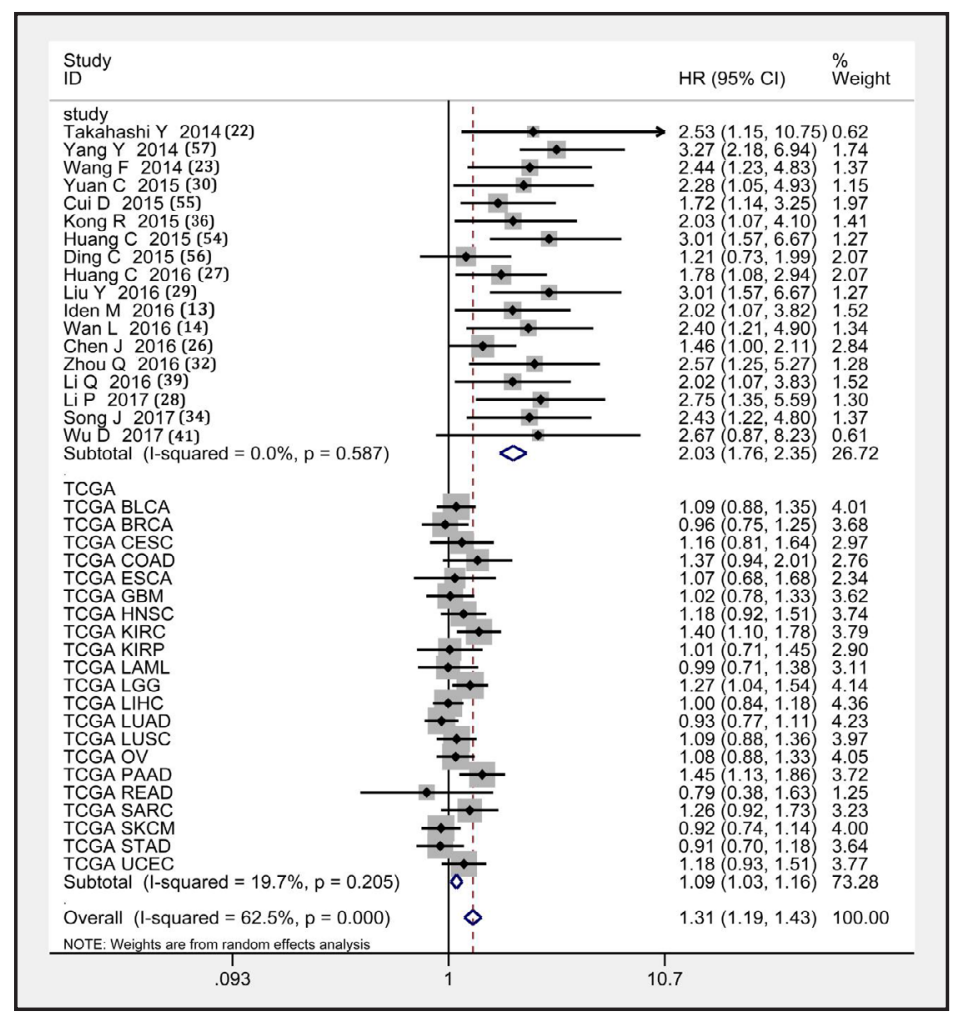

Fig. 3. Subgroup analyses of the overall survival (OS) based upon the tumor type $(\mathrm{P}<0.01$, fixed effect model).

\section{Subgroup analysis \\ Considering}

the existence of heterogeneity in the studies, two subgroup

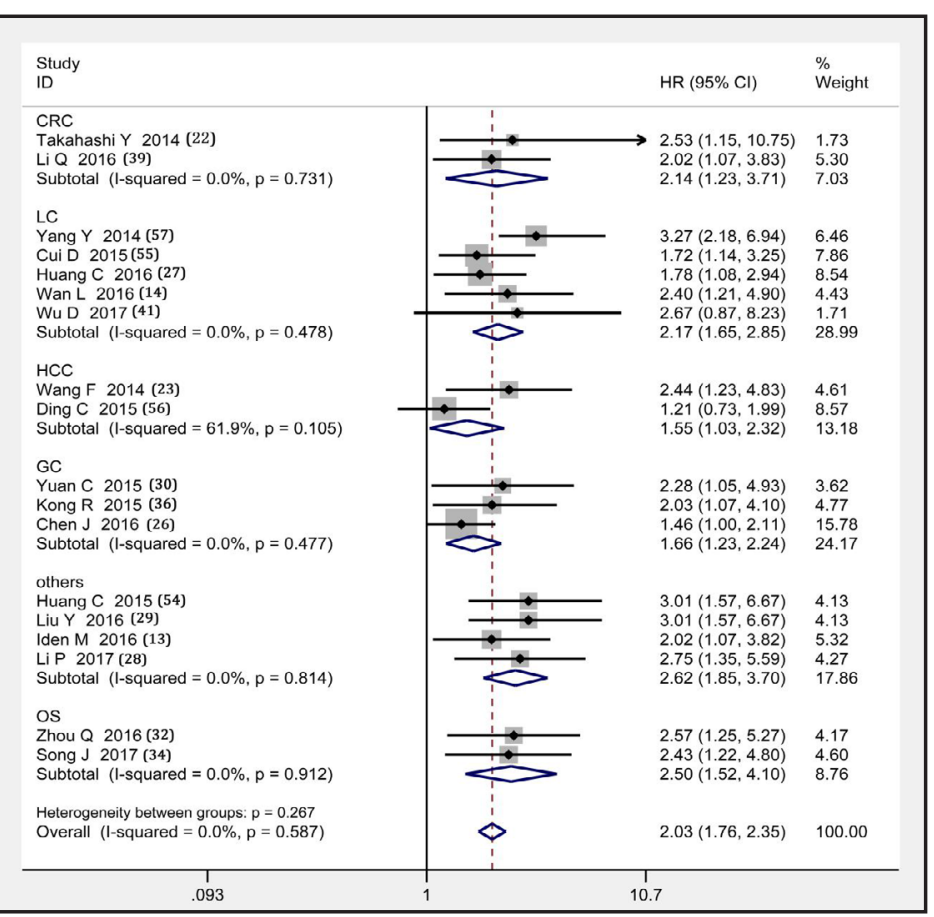
analyses were conducted based upon the sources of survival data and the type of tumors. In the subgroup analysis for overall survival, we found that high expression of PVT1 was markedly associated with a worse overall survival in publications ( $\mathrm{HR}=2.03,95 \% \mathrm{CI}$ : $1.76-2.35, \mathrm{P}<0.01$ ) and TCGA (HR $=1.09,95 \%$ CI: 1.03-1.16, P<0.01) (Fig. 2). Because the studies of colorectal cancer, prostate cancer, ovarian cancer, cervical cancer, and esophageal squamous cell carcinoma were 
Fig. 4. Meta-analysis of selected studies estimating the association of PVT1 with Relapse-free Survival (RFS) and Disease-free Survival (DFS) (P<0.01, fixed effect model).

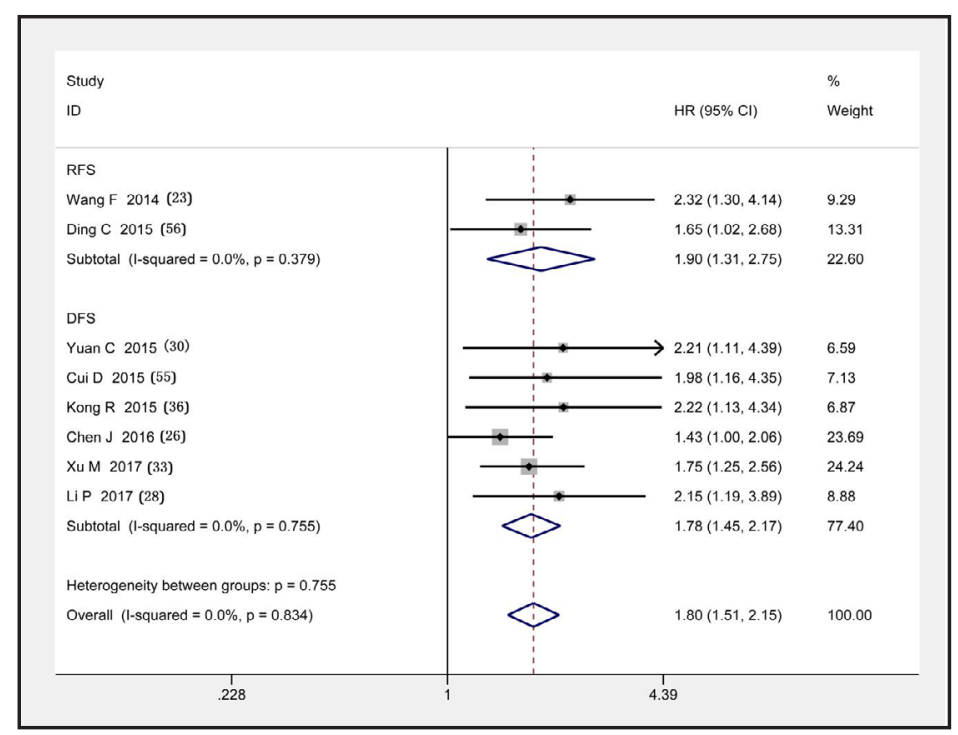

Fig. 5. Meta-analysis estimating the correlation between PVT1 and clinicopathological parameters in cancer patients. ;A, histological differentiation ( $\mathrm{P}<0.01$, fixed effect model); $\mathrm{B}$, TNM stage $(\mathrm{P}<0.01$, fixed effect model); $\mathrm{C}, \mathrm{T}$ classification $(\mathrm{P}<0.01$, random effect model $)$;

single studies, we classified them as others. The same results were identified in the subgroup analysis based upon the tumor type (lung cancer (HR = 2.17, 95\%CI: 1.652.85, $\mathrm{P}<0.01$ ), hepatocellular carcinoma $(\mathrm{HR}=1.55,95 \% \mathrm{CI}: 1.03-2.32, \mathrm{P}=0.035)$, gastric cancer $(\mathrm{HR}=1.66,95 \% \mathrm{CI}$ : $1.23-$ $2.24, \mathrm{P}<0.01)$, osteosarcoma $(\mathrm{HR}=2.50$, 95\%CI: 1.52-4.10, $\mathrm{P}<0.01)$, colorectal cancer (HR $=2.14$, 95\%CI: 1.23-3.71, $\mathrm{P}<0.01$ ) and others including pancreatic cancer, ovarian cancer, cervical cancer, esophageal squamous cell carcinoma (HR $=2.62$, 95\%CI: 1.85-3.70, P<0.01)) (Fig. 3). No heterogeneity was noted among these studies.

\section{Publication bias}

Begg's funnel plots were applied to assess the publication bias in our study. No publication bias was found in the studies estimating the associations of PVT1 with clinicopathological features and DFS. With regard to $0 S$, a publication bias was not observed in the group derived from TCGA ( $\mathrm{P}=0.651)$. However, an asymmetric distribution of Egger's funnel plot appeared in the group of studies $(P=0.01)$; therefore,

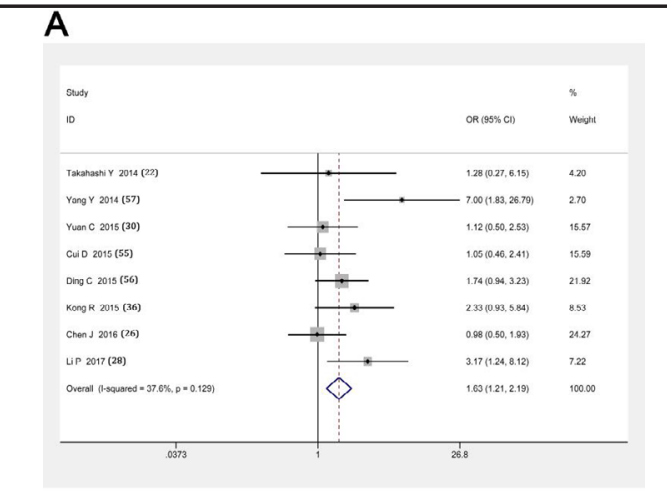

B

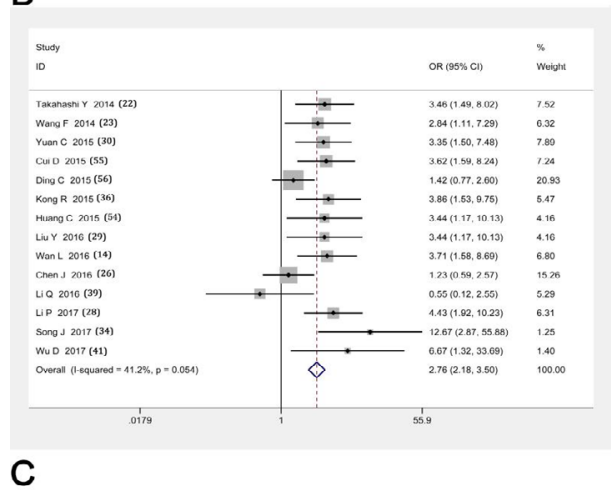

C

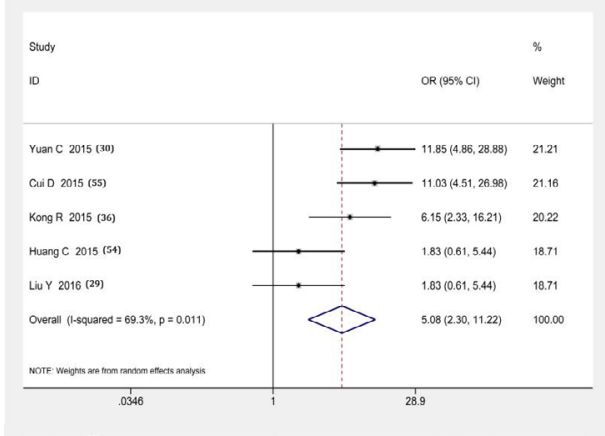


Fig. 6. Meta-analysis estimating the correlation between PVT1 and clinicopathological parameters in cancer patients. A, N classification $(\mathrm{P}=0.013$, random effect model); B, $M$ classification $(\mathrm{P}=0.061$, random effect model); $C$, dender $(\mathrm{P}=0.611$,fixed effect model).

a trim-and-fill method was used to adapt the publication bias. The meta-analysis did not engender conflicting conclusions whether the trim-and-fill method was used or not, suggesting that the results of our study were statistically stable (Fig. 7-9).

\section{TCGA data extraction}

Based upon the results obtained from FireBrowse, PVT1 was highly expressed in 25 of the 37 tumor tissues except for the remaining 12 with missing data (Fig. 10). As shown in Fig. 11 derived from GEPIA, PVT1 was highly expressed in 22 types of cancers and was weakly expressed in 9 tumor tissues.

\section{Function analysis of PVT1-related genes in human tumors}

To explore the potential mechanism of action of PVT1 , a total of 462 target genes were identified with TANRIC and MEM. GO and KEGG analyses were performed. The validated target genes for PVT1 enriched GO terms as follows: (i) biological processes (BPs): positive regulation of cytosolic calcium ion concentration, positive regulation of gene expression, chemical

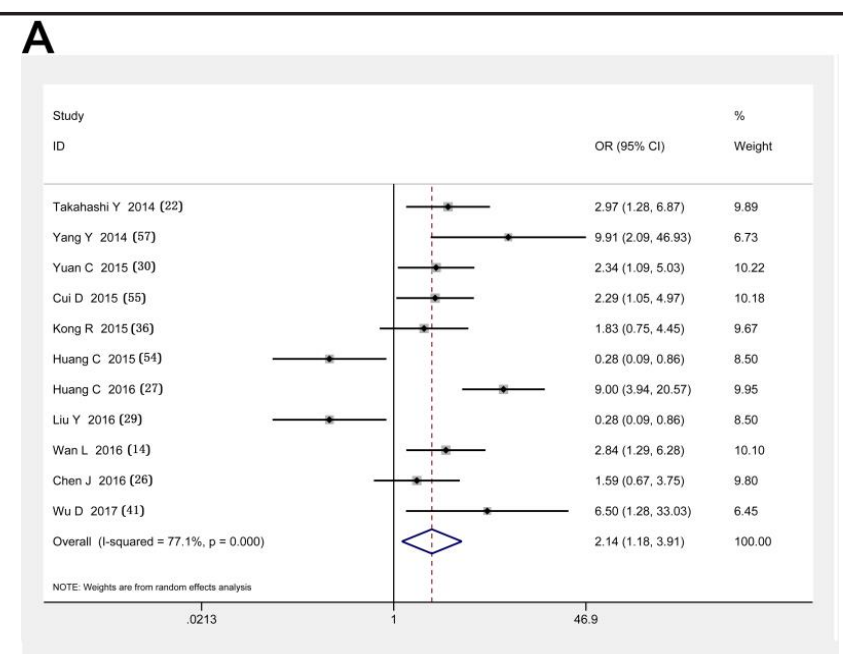

B

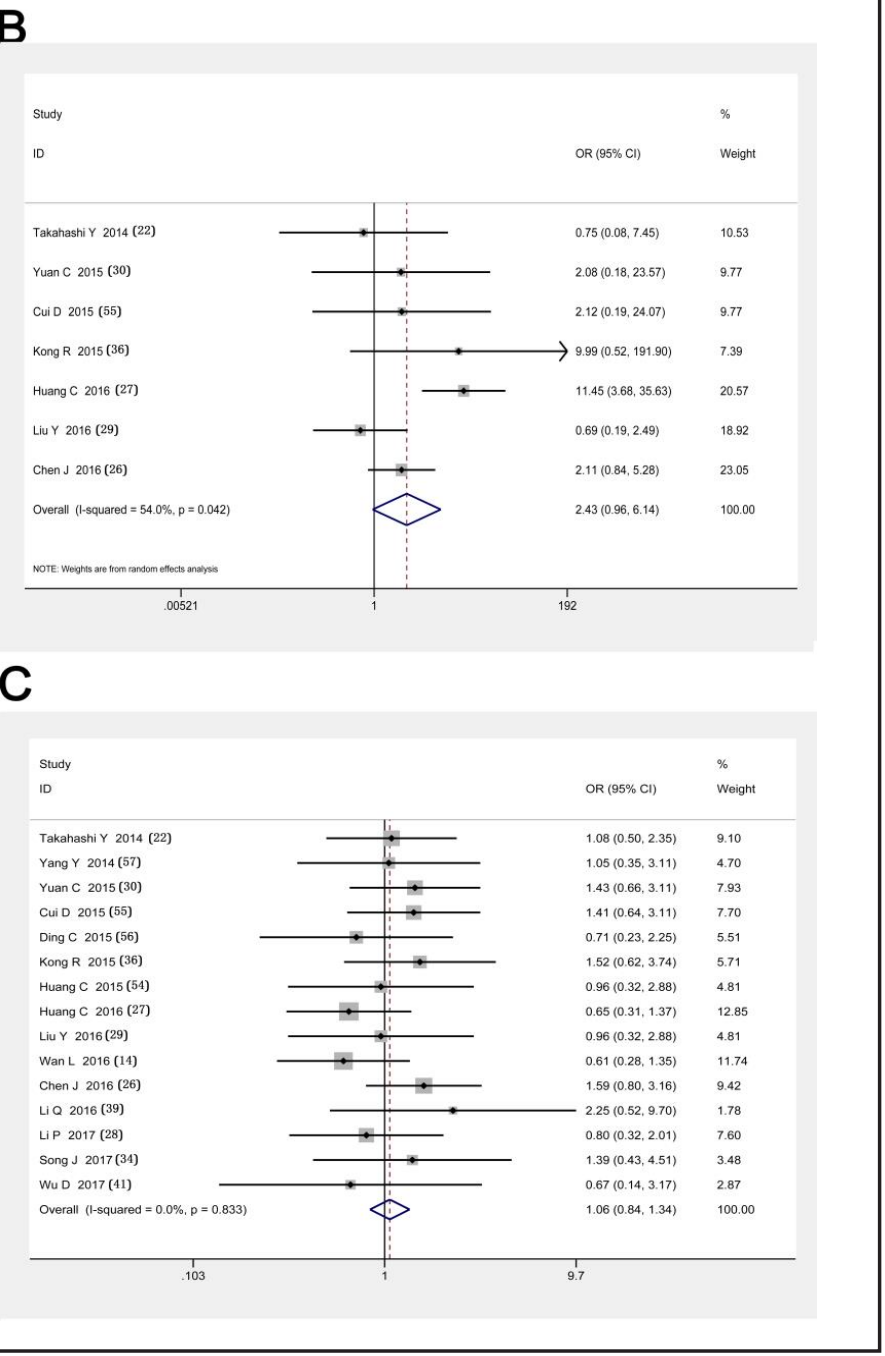
synaptic transmission, for example; (ii) cellular components (CCs): plasma membrane, integral component of plasma membrane, neuronal cell body, membrane, integral component of membrane, for example; and (iii) molecular factors (MFs): calcium ion binding, anion: anion antiporter activity, phosphatidylinositol phospholipase C activity, for example. Furthermore, KEGG enrichment 


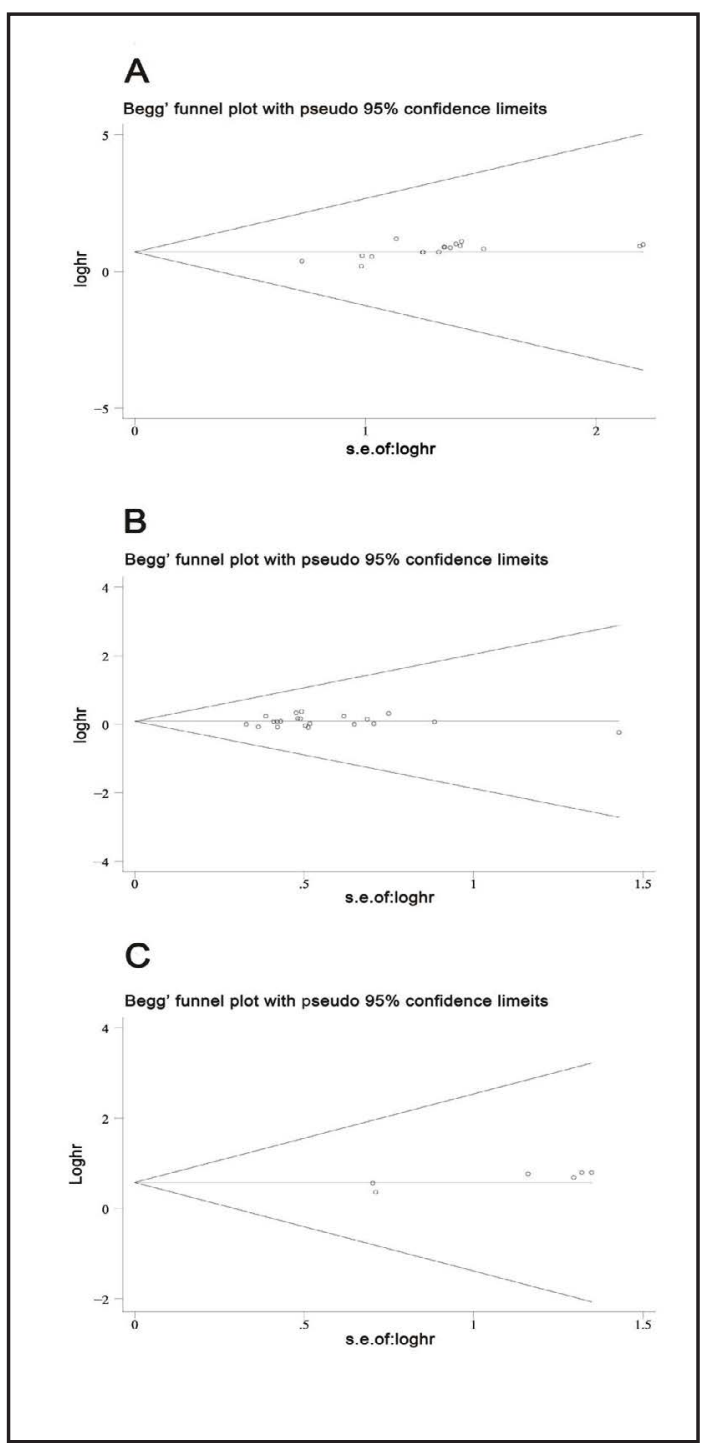

Fig. 7. Funnel plots (Begg's method) of potential publication bias in the selected studies. A, overall survival $(\mathrm{OS})$ of study patients $(\mathrm{P}<0.01)$; $\mathrm{B}$, overall survival $(O S)$ in TCGA data $(\mathrm{P}=0.651)$; $\mathrm{C}$, Diseasefree Survival (DFS) $(\mathrm{P}=0.188)$.
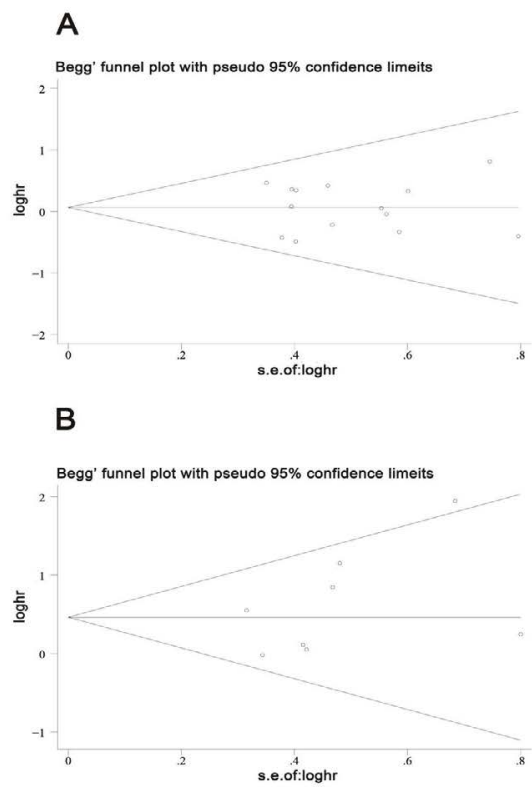

C

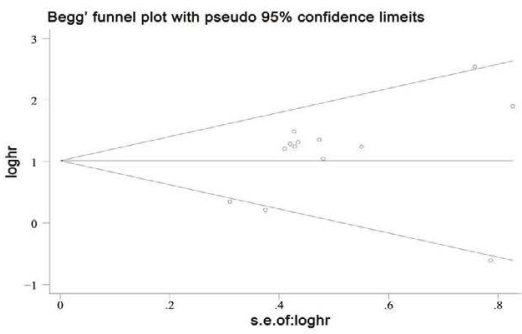

Fig. 8. Funnel plots (Begg's method) of potential publication bias in the selected studies. A, Gender $(\mathrm{P}=0.729)$; $\mathrm{B}$, histological differentiation $(\mathrm{P}=0.138)$; C, TNM stage $(\mathrm{P}=0.25)$.

analysis showed that PVT1 may play a pivotal role in cancers via multiple pathways including the GnRH signaling pathway, Cytokine-cytokine receptor interaction pathway, Inflammatory mediator regulation of TRP channels pathway, and Neuroactive ligand-receptor interaction pathway (Tables. 3-4 and Fig. 12-15).

\section{Discussion}

Numerous studies have shown that a high level of expression of PVT1 was significantly associated with the clinical prognosis and other clinicopathological parameters in cancer patients $[22,23]$. Review articles have also summarized the critical role that PVT1 may play in the progression of a wide range of cancers [24, 25]. A meta-analysis by Liu et al. also suggested that the up-regulation of PVT1 predicted lymph node metastasis and a worse OS in 


\section{Cellular Physiology Cell Physiol Biochem 2018;46:591-608 \begin{tabular}{l|l} 
DOI: 10.1159/000488627 & and Biochemistry \\
Published online: April 04, 2018 & $\begin{array}{l}\text { O } 2018 \text { The Author(s). Published by S. Karger AG, Basel } \\
\text { www.karger.com/cpb }\end{array}$
\end{tabular} \\ He et al.: Prognostic Significance of PVT1 and Target Gene Network in Cancers}

cancer patients, although the association between PVT1 and other clinicopathological parameters was not discussed [15]_ENREF_15. In addition, other publications since 2015 have continued to investigate the association between PVT1 expression and the prognosis of cancer patients $[13,14,26-35]$. To reach a more convincing conclusion and explore the potential mechanism of action of PVT1 in tumors, we performed the current study by merging the results of published studies and TCGA survival data and conducting GO and KEGG analyses.

The current meta-analysis of 2006 patients from 19 eligible studies and 7966 patients from TCGA explored the associations between high expression of PVT1 and the prognosis, as well as clinicopathological features in cancer patients. To the best of our knowledge, our study is the most comprehensive analysis to date. We evaluated the quality of all the selected studies by NOS, and a trim-and-fill test was used to examine the publication bias. If the p value of Begg's test was less than 0.05 , we also checked the reliability of the results by sensitivity analysis. Our results showed that the high expression of PVT1 was apparently related to worse clinical outcomes, including OS was 1.31 (95\% CI: 1.19-1.43), DFS (HR=1.78, 95\%CI: 1.45-2.17), and RFS (HR=1.90, 95\% CI: 1.31-2.75). For the clinicopathological features of patients with cancers, our study indicated that high PVT1 was significantly associated with the aggression of cancers, including histological differentiation $(\mathrm{OR}=1.63$, 95\%CI: 1.21-2.19), TNM stages (OR $=2.76$, 95\%CI: 2.18-3.50), $\mathrm{T}$ stages (OR $=5.08,95 \% \mathrm{CI}: 2.30-11.22)$ and lymph node metastasis (OR $=2.14,95 \%$ CI: 1.18-3.91). A subgroup analysis suggested that high PVT1 expression is significantly correlated with overall survival, both in the publications (HR $=2.03,95 \% \mathrm{CI}$ : 1.76-2.35) and TCGA (HR=1.09, 95\%CI: 1.03-1.16). Simultaneously, subgroup analysis also showed that PVT1 was significantly associated with all types of cancer. PVT1 appears to be a potential biomarker reflecting the progression and prognosis of cancer based upon the results of our study. However, rectum adenocarcinoma (READ), skin cutaneous melanoma (SKCM), and stomach adenocarcinoma (SKAD) in the TCGA dataset were correlated with a good prognosis although the results were not statistically significant; their corresponding $\mathrm{HR}$ values were $0.786(95 \% \mathrm{CI}: 0.379-1.629, \mathrm{P}=0.517), 0.92(95 \% \mathrm{CI}: 0.742-1.141$, $\mathrm{P}=0.449)$ and $0.912(95 \% \mathrm{CI}: 0.702-1.183, \mathrm{P}=0.486)$, respectively. We reviewed the relevant studies and found that the high PVT1 level was associated with worse outcomes in gastric cancer and colorectal cancer $[22,26,30,33,36]$ and that there was no corresponding report for melanoma. The inconsistent results in the TCGA and literature studies in these tumors may be caused by sampling error and publication bias. Additional studies are needed to confirm the association between PVT1 and prognosis in different types of cancer.

In the current meta-analysis, significant heterogeneity was present in the studies with OS $(\mathrm{P}<0.05)$ when combining the HR values from publications. Heterogeneity also emerged in the studies of the clinicopathological features, including $\mathrm{T}$ classification, lymph node metastasis and $\mathrm{M}$ classification $(\mathrm{P}<0.05)$. Considering that the presence of heterogeneity may 


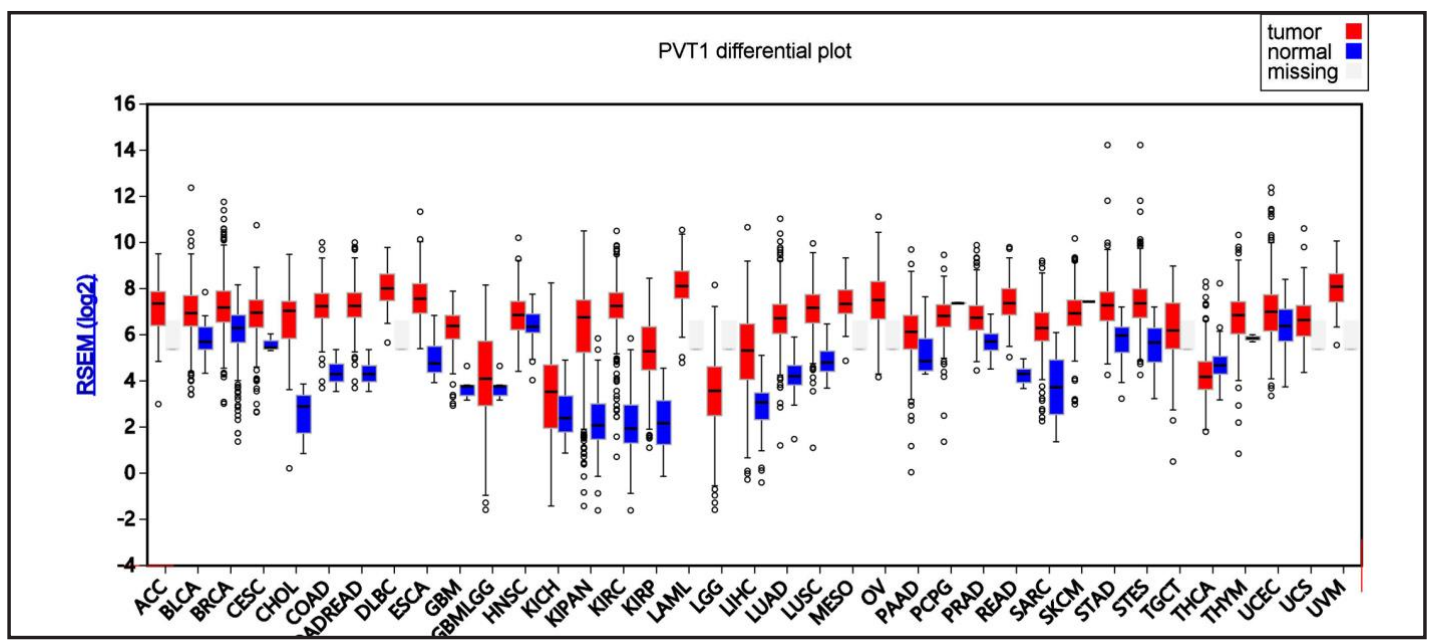

Fig. 10. PVT1 expression profile across tumor samples and adjacent normal tissues from FireBrowse (box plot).

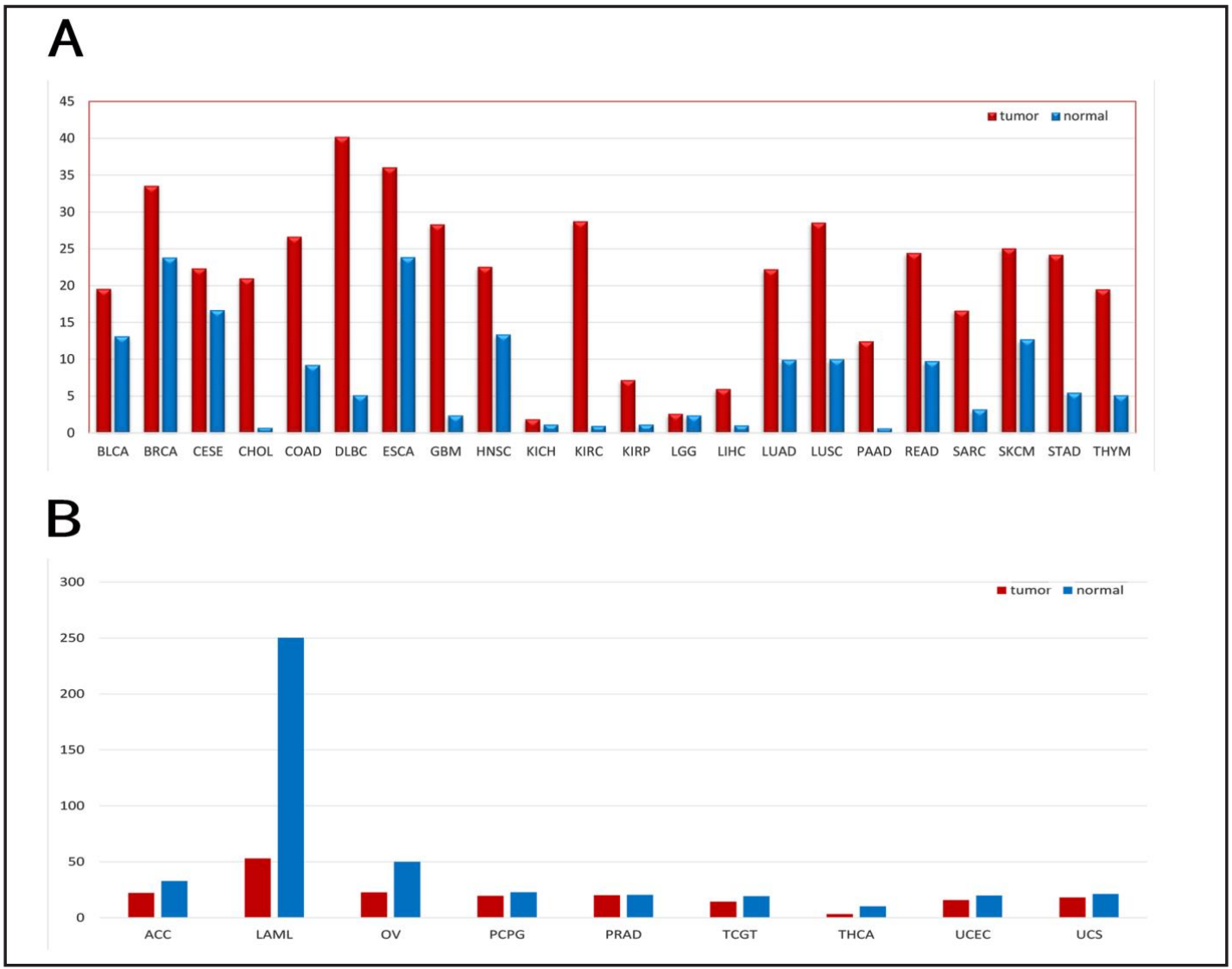

Fig. 11. PVT1 expression profile across tumor samples and paired normal tissues from GEPIA (barplot). The height of the bar represents the median expression of certain tumor types or normal tissues. A, the level of PVT1 expression was higher in tumor than in adjacent normal tissue; B, the level of PVT1 was lower in tumor than in adjacent normal tissue.

influence the results of the meta-analysis, we have treated the heterogeneity carefully [37] ENREF_37 with a random effect model to reduce the effect of heterogeneity on the merged result in our study. A publication bias was also noted in studies with 0 data $(P=0.01)$ as 


\begin{tabular}{|c|c|c|}
\hline ılar Physiol & Cell Physiol Biochem 2018; & 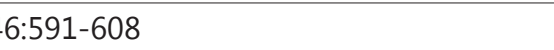 \\
\hline and Biochemistry & $\begin{array}{l}\text { DOI: 10.1159/000488627 } \\
\text { Published online: April 04, } 2018\end{array}$ & $\begin{array}{l}\text { O } 2018 \text { The Author(s). Published by S. Karger AG, Basel } \\
\text { www.karger.com/cpb }\end{array}$ \\
\hline
\end{tabular}

He et al.: Prognostic Significance of PVT1 and Target Gene Network in Cancers

Table 3. GO functional annotation of the most significant related targets of PVT1

\begin{tabular}{|c|c|c|c|c|}
\hline GO ID & GO term & $\begin{array}{c}\text { Count } \\
(\%)\end{array}$ & Gene symbol & $P$ \\
\hline \multicolumn{5}{|l|}{$\begin{array}{l}\text { Biological } \\
\text { process }\end{array}$} \\
\hline GO:0007204 & $\begin{array}{c}\text { positive regulation of cytosolic calcium ion } \\
\text { concentration }\end{array}$ & 19 & $\begin{array}{l}\text { KNG1, PTGER3, CCKBR, SWAP70, OPRL1, ESR1, } \\
\text { LPAR3, CXCR3, etc }\end{array}$ & $7.60 \mathrm{E}-09$ \\
\hline GO:0010628 & positive regulation of gene expression & 19 & $\begin{array}{l}\text { E2F1, NOS1AP, CSF1, PIK3CD, HFE, PTPN22, } \\
\text { HCFC1, LEF1, MAPK11, etc }\end{array}$ & $1.25 \mathrm{E}-04$ \\
\hline GO:0007268 & chemical synaptic transmission & 18 & $\begin{array}{l}\text { SNCG, MPZ, NRXN2, OPRL1, PCDHB3, CPNE6, } \\
\text { CACNB1, PCDHB2, etc }\end{array}$ & 1.33E-04 \\
\hline GO:0007155 & cell adhesion & 24 & $\begin{array}{l}\text { IBSP, ACHE, ICAM4, PCDHB3, LRRN2, MYBPC3, } \\
\text { PCDHB2, ACTN2, etc }\end{array}$ & 0.001469 \\
\hline GO:0006954 & inflammatory response & 21 & $\begin{array}{l}\text { CIITA, KNG1, IL18RAP, PTGER3, TNFRSF25, } \\
\text { AIF1, IL1RL2, CSF1, etc }\end{array}$ & 0.001613 \\
\hline GO:0002230 & $\begin{array}{c}\text { positive regulation of defense response to virus by } \\
\text { host }\end{array}$ & 5 & LILRB1, IL12RB1, IL23A, PTPN22, APOBEC3G & 0.002043 \\
\hline GO:0043401 & steroid hormone mediated signaling pathway & 7 & $\begin{array}{l}\text { ESRRA, NR1I2, THRA, ESR1, LEF1, HNF4G, } \\
\text { NR2C1 }\end{array}$ & 0.00306 \\
\hline GO:0070588 & calcium ion transmembrane transport & 10 & $\begin{array}{l}\text { ATP2B2, TRPV1, ATP2A1, CACNB1, CACNG4, } \\
\text { CACNG2, CACNB4, etc }\end{array}$ & 0.003213 \\
\hline GO:0060041 & retina development in camera-type eye & 7 & $\begin{array}{l}\text { MAX, TUB, ACHE, CLCN2, LHX2, NTRK2, } \\
\text { SLC4A5 }\end{array}$ & 0.003342 \\
\hline $\begin{array}{l}\text { GO:0007202 } \\
\text { Cellular } \\
\text { component }\end{array}$ & activation of phospholipase C activity & 5 & S1PR4, AVPR1A, ADRA1A, LPAR1, PLCB2 & 0.003857 \\
\hline GO:0005886 & plasma membrane & 163 & $\begin{array}{c}\text { F2RL2, ADCY2, CROCC, EFNA3, SLC9A2, LPAR3, } \\
\text { SLC22A11, LPAR1, etc }\end{array}$ & $5.18 \mathrm{E}-12$ \\
\hline GO:0005887 & integral component of plasma membrane & 75 & $\begin{array}{l}\text { F2RL2, ADCY2, MSR1, TRPV1, EFNA3, LPAR3, } \\
\text { SLC22A11, LPAR1, etc }\end{array}$ & $1.57 \mathrm{E}-10$ \\
\hline GO:0043025 & neuronal cell body & 20 & $\begin{array}{c}\text { UBXN1, SNCG, CPLX2, TRPV1, HCFC1, LPAR1, } \\
\text { TMPRSS5, ITPR3, etc }\end{array}$ & $2.44 \mathrm{E}-04$ \\
\hline GO:0016020 & membrane & 77 & $\begin{array}{c}\text { ADCY2, MSR1, QPCTL, AP1G2, PKMYT1, VPS53, } \\
\text { RPS3, IGHMBP2, etc }\end{array}$ & $7.13 \mathrm{E}-04$ \\
\hline GO:0016021 & integral component of membrane & 155 & $\begin{array}{l}\text { F2RL2, ADCY2, QPCTL, B3GALT4, SLC9A2, } \\
\text { SLC22A11, GDAP1 L1, etc }\end{array}$ & 0.001083 \\
\hline GO:0005929 & cilium & 10 & $\begin{array}{l}\text { SMO, ATP2B2, TUB, EVC, FAM49B, CCDC40, } \\
\text { ADCY10, ATP6 V1D, ARL3, etc }\end{array}$ & 0.011024 \\
\hline GO:0031095 & platelet dense tubular network membrane & 3 & ATP2A1, ITPR3, ITPR2 & 0.018633 \\
\hline GO:0005891 & voltage-gated calcium channel complex & 4 & CACNB1, CACNG4, CACNG2, CACNB4 & 0.031914 \\
\hline GO:0009897 & external side of plasma membrane & 11 & $\begin{array}{l}\text { NCAM1, LILRB1, ECE1, IL12RB1, CD80, TRPV1, } \\
\text { TFR2, TNFRSF13B, etc }\end{array}$ & 0.034066 \\
\hline GO:0032580 & Golgi cisterna membrane & 6 & $\begin{array}{c}\text { GALNT3, GOLGA8B, FUT7, ST3GAL4, GOLIM4, } \\
\text { HMP19 }\end{array}$ & 0.036364 \\
\hline \multicolumn{5}{|l|}{$\begin{array}{l}\text { Molecular } \\
\text { function }\end{array}$} \\
\hline GO:0005509 & calcium ion binding & 33 & $\begin{array}{l}\text { GALNT3, S100A3, ENPP1, MASP1, AIF1, } \\
\text { KCNIP2, ATP2B2, MMP20, etc }\end{array}$ & $9.81 \mathrm{E}-04$ \\
\hline GO:0015301 & anion:anion antiporter activity & 5 & $\begin{array}{l}\text { SLC22A7, SLC22A8, SLC26A10, SLC26A1, } \\
\text { SLC4A5 }\end{array}$ & 0.002259 \\
\hline GO:0004435 & phosphatidylinositol phospholipase C activity & 5 & PLCL2, F2RL2, CCKBR, PLCB1, PLCB2 & 0.004141 \\
\hline GO:0005262 & calcium channel activity & 7 & $\begin{array}{c}\text { TRPV1, CACNG4, CACNG2, CACNB4, ITPR3, } \\
\text { PKDREJ, TRPM2 }\end{array}$ & 0.00768 \\
\hline GO:0004872 & receptor activity & 13 & $\begin{array}{l}\text { AMHR2, IL18RAP, LILRA2, TNFRSF25, LRRN2, } \\
\text { SIGLEC7, TNFRSF13B, etc }\end{array}$ & 0.008029 \\
\hline GO:0003707 & steroid hormone receptor activity & 6 & ESRRA, NR1I2, THRA, ESR1, HNF4G, NR2C1 & 0.012336 \\
\hline GO:0015347 & $\begin{array}{l}\text { sodium-independent organic anion } \\
\text { transmembrane transporter activity }\end{array}$ & 4 & SLC22A7, SLC22A8, SLC22A11, SLCO5A1 & 0.014394 \\
\hline GO:0003700 & $\begin{array}{l}\text { transcription factor activity, sequence-specific } \\
\text { DNA binding }\end{array}$ & 36 & $\begin{array}{l}\text { E2F1, POU6F1, RAI1, THRA, SPI1, HCFC1, } \\
\text { ZBTB17, NR2C1, FOXH1, etc }\end{array}$ & 0.01465 \\
\hline GO:0004887 & thyroid hormone receptor activity & 3 & NR1I2, THRA, BRD8 & 0.015515 \\
\hline GO:0008307 & structural constituent of muscle & 5 & OBSCN, MYBPC3, ACTN2, ASPH, NEBL & 0.019768 \\
\hline
\end{tabular}

Table 4. KEGG pathway enrichment analysis of PVT1 target genes

\begin{tabular}{|c|c|c|c|c|}
\hline KEGG ID & KEGG term & $\begin{array}{c}\text { Count } \\
(\%)\end{array}$ & Gene symbol & $\mathrm{P}$ \\
\hline hsa04912 & GnRH signaling pathway & 11 & $\begin{array}{l}\text { PLD2, ADCY2, SOS2, MAPK11, MMP14, PLCB1, ITPR3, PLCB2, } \\
\text { LHB, MAP2K6, ITPR2 }\end{array}$ & $5.66 \mathrm{E}-04$ \\
\hline hsa04060 & $\begin{array}{l}\text { Cytokine-cytokine receptor } \\
\text { interaction }\end{array}$ & 18 & $\begin{array}{l}\text { AMHR2, IL18RAP, TNFRSF25, CTF1, CSF1, TNFRSF13B, IL21R, } \\
\text { EDAR, CXCR3, CCL25, etc }\end{array}$ & $9.55 \mathrm{E}-04$ \\
\hline hsa04750 & $\begin{array}{l}\text { Inflammatory mediator regulation of } \\
\text { TRP channels }\end{array}$ & 11 & $\begin{array}{l}\text { ADCY2, TRPV1, PIK3CD, PLA2G6, MAPK11, PIK3R5, PLCB1, } \\
\text { ITPR3, PLCB2, MAP2K6, ITPR2 }\end{array}$ & 0.001017607 \\
\hline hsa 04080 & $\begin{array}{c}\text { Neuroactive ligand-receptor } \\
\text { interaction }\end{array}$ & 20 & $\begin{array}{l}\text { F2RL2, THRA, PTGER3, CCKBR, TRPV1, OPRL1, LPAR3, LPAR1, } \\
\text { ADORA1, PLG, CRHR2, etc }\end{array}$ & 0.001191953 \\
\hline hsa04630 & Jak-STAT signaling pathway & 13 & $\begin{array}{c}\text { CTF1, PIK3CD, IL21R, STAT2, IL23A, IL12RB1, SOS2, IL12A, } \\
\text { PIK3R5, JAK3, IL5RA, AKT3, IL3RA }\end{array}$ & 0.002092022 \\
\hline hsa04261 & $\begin{array}{l}\text { Adrenergic signaling in } \\
\text { cardiomyocytes }\end{array}$ & 13 & $\begin{array}{l}\text { ADCY2, PIK3CD, CACNB1, CACNG4, MAPK11, CACNB4, CACNG2, } \\
\text { ATP2B2, ADRA1A, etc }\end{array}$ & 0.002217002 \\
\hline hsa04725 & Cholinergic synapse & 11 & $\begin{array}{l}\text { ACHE, ADCY2, PIK3CD, PIK3R5, CHRNA6, GNG4, PLCB1, ITPR3, } \\
\text { PLCB2, AKT3, ITPR2 }\end{array}$ & 0.002619522 \\
\hline hsa 04380 & Osteoclast differentiation & 12 & $\begin{array}{l}\text { LILRB1, LILRA2, FCGR2C, CSF1, PIK3CD, LILRA5, SPI1, } \\
\text { MAPK11, PIK3R5, AKT3, MAP2K6, STAT2 }\end{array}$ & 0.002839608 \\
\hline hsa04915 & Estrogen signaling pathway & 10 & $\begin{array}{l}\text { ADCY2, PIK3CD, SOS2, ESR1, PIK3R5, PLCB1, ITPR3, PLCB2, } \\
\text { AKT3, ITPR2 }\end{array}$ & 0.003992286 \\
\hline hsa04062 & Chemokine signaling pathway & 14 & $\begin{array}{c}\text { ADCY2, PIK3CD, CXCR3, STAT2, CCL25, CCR3, SOS2, PIK3R5, } \\
\text { JAK3, PLCB1, GNG4, XCR1, etc }\end{array}$ & 0.006027544 \\
\hline
\end{tabular}

shown by Begg's test and funnel plots. Hence, a trim-and-fill method was used to adapt the publication bias and the results were consistent with the previous one which suggested that the results of our study were statistically stable. 
Fig. 12. Significantly enriched annotation of (Gene Ontology) GO categories and (Kyoto Encyclopedia of Genes and Genomes) KEGG pathways of potential mRNA targets of IncRNA PVT1 in cancer patients. A, biological processes (BP); B, cellular components (CC); C, molecular factors (MF); D, KEGG pathway.

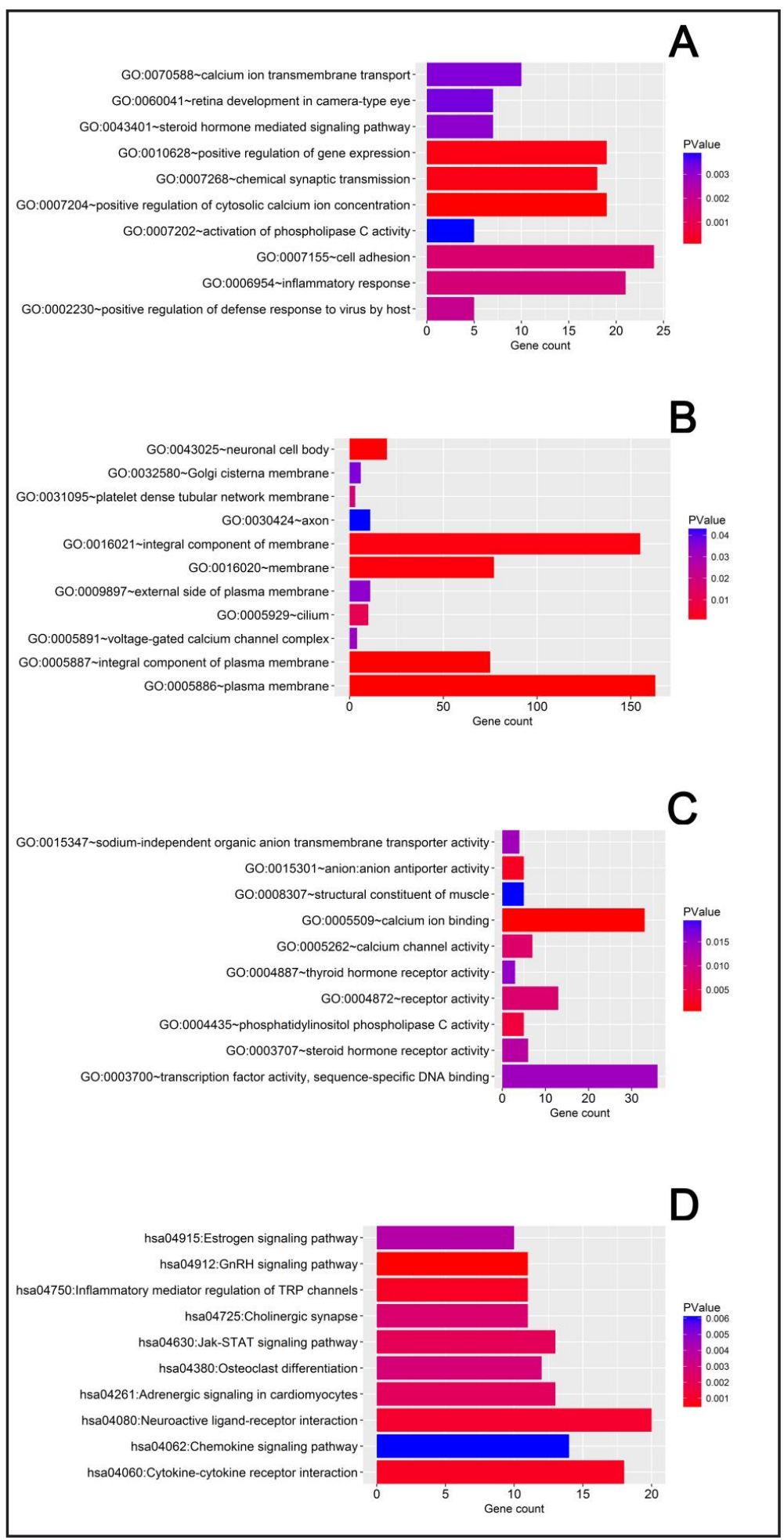

Studies have shown that the level of PVT1 expression was clearly up-regulated in cancer tissues compared with paired adjacent tissues [31,38-41], The same result was also detected in cell line samples in vitro [34, 42]. In recent years, studies on the mechanism of action of PVT1 in cancer have proliferated, and increasing evidence suggested that PVT1 could affect diverse biological behaviors of multiple tumors. Yan et al. observed that the expression of PVT1 was positively associated to miR-1207-5p, which promoted the breast cancer cell 
Fig. 13. Gene o n t o l o g y (GO) analysis of the b i o log i cal process (BP) category.

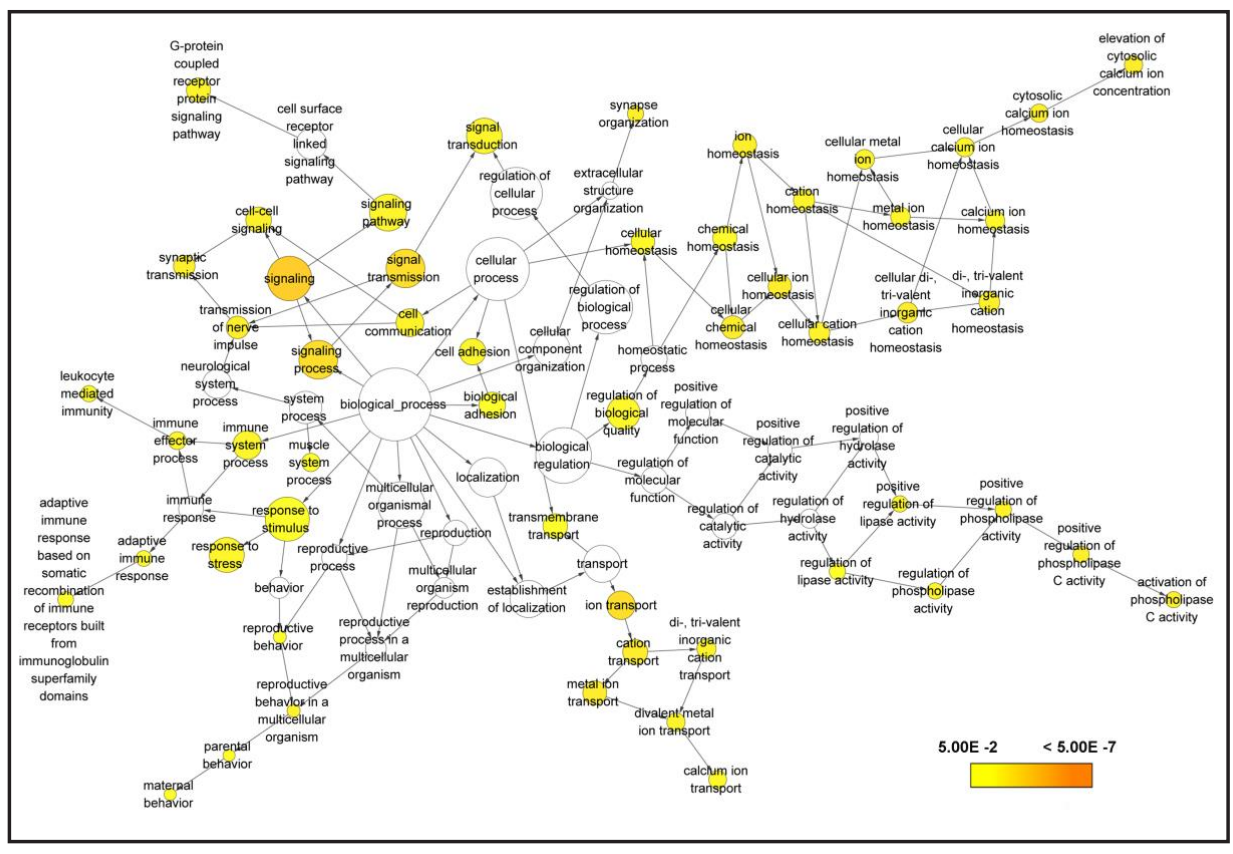

Fig. $\quad 14$. Gene Ontology (GO) analysis of the cellular component (CC) category.

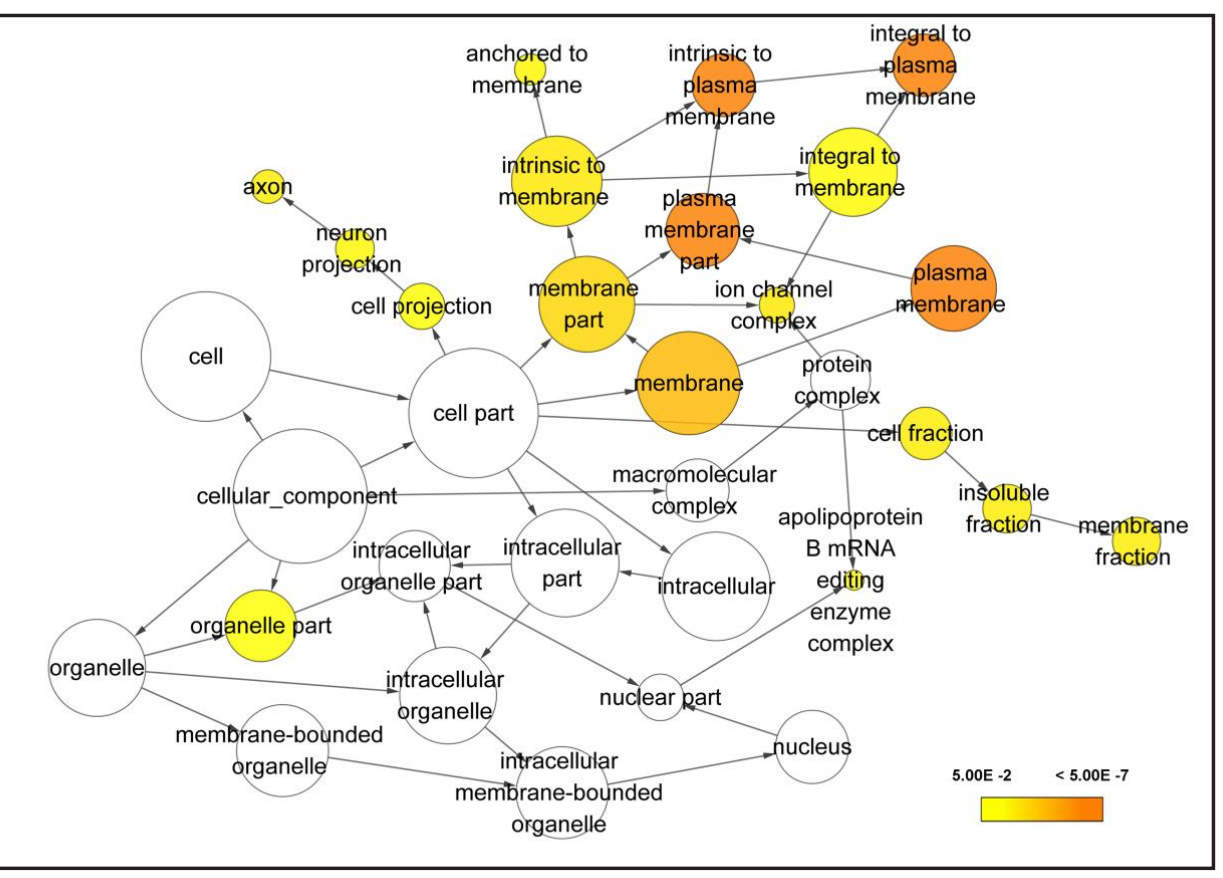

proliferation by targeting STAT6 [43]. Ma et al. revealed that PVT1 was highly expressed in glioma vascular endothelial cells, which increased the expression of Beclin1 and Atg7 by targeting miR-186, thereby promoting cell proliferation, migration and angiogenesis [44]. Lan et al. discovered that PVT1 acts as an endogenous sponge of miR-186-5p to reduce its inhibitory effect on yes-associated protein 1, promoting the tumorigenesis of hepatocellular carcinoma [45]. Although advances were made in the understanding of the role of PVT1 in tumors, its precise molecular mechanisms underlying its function are still unclear. Hence, we collected the validated targeting genes of PVT1 using MEM and TANRIC Platform and performed a comprehensive target gene network analysis. The GO and KEGG pathway analysis demonstrated that PVT1 may play a pivotal role in the human tumors via different 


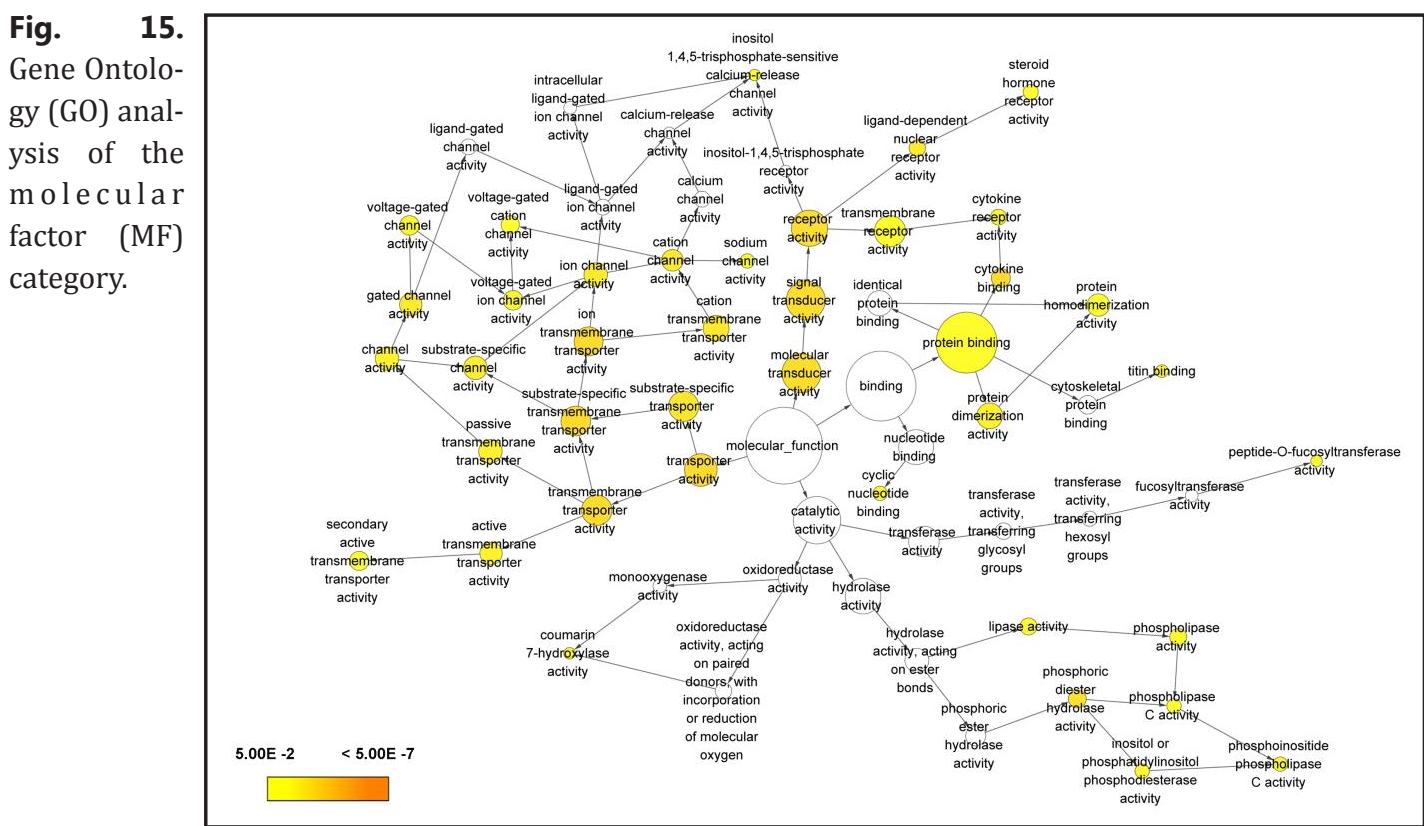

pathways, including GnRH signaling pathway, Cytokine-cytokine receptor interaction pathway, Inflammatory mediator regulation of TRP channels pathway and Neuroactive ligand-receptor interaction pathway. The hypothalamic decapeptide gonadotropin-releasing hormone (GnRH), also identified as luteinizing hormone-releasing hormone (LHRH), may play a crucial part in the regulation of mammalian reproduction $[46,47]$. GnRH binds to a specific GnRH receptor, a member of the large superfamily of seven transmembrane domain receptors that bind to G-proteins [48, 49]. Studies revealed that GnRH receptors is expressed in breast, ovarian, endometrial and prostate_ENREF_50 cancers and that the proliferation in vitro can be repressed by agonistic or antagonistic analogs in various human cancer cell lines [50-53]. Our study found that PVT1 is involved in tumor progression by regulating the GnRH pathway. These findings were in agreement with the previous reports that PVT1 increased the proliferation, invasion, and migration in gynecological tumor cells and was associated with poor prognosis $[13,29]$.

There are several limitations to our study. For the meta-analysis, different cut off values for PVT1 in the selected studies were a factor in yielding Publication bias. Meanwhile, since there were no direct results of multivariate analysis in some eligible studies, we had to extract the relevant data through the Kaplan-Meier Curve, which may lead to a deviation of HR values. Moreover, the diagnostic value of PVT1 in cancers was not evaluated in the current meta-analysis for lack of enough diagnostic data of PVT1 from the literature research. Hence, further study is needed to explore the clinical significance and diagnostic value of PVT1 in human cancers. In addition, although PVT1 can act through various mechanisms, only one possible mechanism for the role of PVT1 in gene regulation was investigated based upon the correlation of gene expression levels between PVT1 and mRNA. For a better understanding of PVT1 functions, further research is warranted to explore other possible mechanisms.

\section{Conclusion}

Our study demonstrated that higher PVT1 expression was significantly associated with an aggressive disease course in patients with cancer, predicting a poorer TNM stage, invasion depth, lymph node metastasis, and distant metastasis and shorter OS, DFS, and RFS times. We also demonstrated that PVT1 plays an essential role in biological processes via a variety of pathways. Considering the limitations of the current analysis, further studies are warranted to explore the function of PVT1 and its relationship with cancers. 


\section{Cellular Physiology Cell Physiol Biochem 2018;46:591-608 \begin{tabular}{l|l} 
DOI: 10.1159/000488627 & and Biochemistry \\
Published online: April 04, 2018 & $\begin{array}{l}\text { O } 2018 \text { The Author(s). Published by S. Karger AG, Basel } \\
\text { www.karger.com/cpb }\end{array}$
\end{tabular}}

He et al.: Prognostic Significance of PVT1 and Target Gene Network in Cancers

\section{Acknowledgements}

The study was supported by the funds of National Natural Science Foundation of China (NSFC 81560469, NSFC 81360327), Natural Science Foundation of Guangxi, China (2015GXNSFCA139009) and Guangxi Medical University Training Program for Distinguished Young Scholars (2017).

\section{Disclosure Statement}

The authors declare that they have no conflicts of interest.

\section{References}

1 Yan B, Wang Z: Long noncoding rna: Its physiological and pathological roles. DNA Cell Biol 2012;31:S-34-S-41.

2 Uchida S, Dimmeler S: Long noncoding rnas in cardiovascular diseases. Circ Res 2015;116:737.

-3 Jian L, Jian D, Chen Q, Zhang L: Long noncoding rnas in atherosclerosis. J Atheroscler Thromb 2015;23:376.

- 4 Bhan A, Soleimani M, Mandal SS: Long noncoding rna and cancer: A new paradigm. Cancer Res 2017;77:3965.

5 Kocerha J, Dwivedi Y, Brennand KJ: Noncoding rnas and neurobehavioral mechanisms in psychiatric disease. Mol Psychiatry 2015;20:677-684.

6 Nobili L, Ronchetti D, Taiana E, Neri A: Long non-coding rnas in b-cell malignancies: A comprehensive overview. Oncotarget 2017;8:60605.

7 Tang J, Jiang R, Deng L, Zhang X, Wang K, Sun B: Circulation long non-coding rnas act as biomarkers for predicting tumorigenesis and metastasis in hepatocellular carcinoma. Oncotarget 2015;6:4505-4515.

8 Cory S, Graham M, Webb E, Corcoran L, Adams JM: Variant $(6 ; 15)$ translocations in murine plasmacytomas involve a chromosome 15 locus at least $72 \mathrm{~kb}$ from the c-myc oncogene. EMBO J 1985;4:675.

-9 Webb E, Adams JM, Cory S: Variant $(6 ; 15)$ translocation in a murine plasmacytoma occurs near an immunoglobulin | [kappa]| gene but far from the myc oncogene. Nature 1984;312:777-779.

10 Huppi K, Siwarski D: Chimeric transcripts with an open reading frame are generated as a result of translocation to the pvt-1 region in mouse b-cell tumors. Int J Cancer 1994;59:848.

11 Shtivelman E, Bishop JM: Effects of translocations on transcription from pvt. Mol Cell Biol 1990;10:1835.

12 Zeng C, Yu X, Lai J, Yang L, Chen S, Li Y: Overexpression of the long non-coding rna pvt1 is correlated with leukemic cell proliferation in acute promyelocytic leukemia. J Hematol Oncol2015;8:1-6.

13 Iden M, Fye S, Li K, Chowdhury T, Ramchandran R, Rader JS: The Incrna pvt1 contributes to the cervical cancer phenotype and associates with poor patient prognosis. PLoS One 2016;11:e0156274.

14 Wan L, Sun M, Liu GJ, Wei CC, Zhang EB, Kong R, Xu TP, Huang MD, Wang ZX: Long noncoding rna pvt1 promotes non-small cell lung cancer cell proliferation through epigenetically regulating lats2 expression. Mol Cancer Ther 2016;15:1082-1094.

-15 Liu FT, Xue QZ, Zhu ZM, Qiu C, Hao TF, Zhu PQ, Luo HL: Long noncoding rna pvt1, a novel promising biomarker to predict lymph node metastasis and prognosis: A meta-analysis. Panminerva Med 2016;58:160.

16 Tierney JF, Stewart LA, Ghersi D, Burdett S, Sydes MR: Practical methods for incorporating summary timeto-event data into meta-analysis. Trials 2007;8:16.

17 Stang A: Critical evaluation of the newcastle-ottawa scale for the assessment of the quality of nonrandomized studies in meta-analyses. Eur J Epidemiol2010;25:603.

18 Anaya J: Oncolnc: Linking tcga survival data to mrnas, mirnas, and lncrnas. Peerj Computer Science 2016;2:e67.

19 Li J, Han L, Roebuck P, Diao L, Liu L, Yuan Y, Weinstein JN, Liang H: Tanric: An interactive open platform to explore the function of Incrnas in cancer. Cancer Res 2015;75:3728-3737. 


\section{Cellular Physiology Cell Physiol Biochem 2018;46:591-608 \begin{tabular}{l|l} 
DOI: 10.1159/000488627 & Ond Biochemistry \\
Published online: April 04, 2018 & $\begin{array}{l}\text { O } 2018 \text { The Author(s). Published by S. Karger AG, Basel } \\
\text { www.karger.com/cpb }\end{array}$
\end{tabular}}

He et al.: Prognostic Significance of PVT1 and Target Gene Network in Cancers

20 Ashburner M, Ball CA, Blake JA, Botstein D, Butler H, Cherry JM, Davis AP, Dolinski K, Dwight SS, Eppig JT, Harris MA, Hill DP, Issel-Tarver L, Kasarskis A, Lewis S, Matese JC, Richardson JE, Ringwald M, Rubin GM, Sherlock G: Gene ontology: Tool for the unification of biology. Nat Genet 2000;25:25-29.

21 Kanehisa M, Goto S, Sato Y, Furumichi M, Tanabe M: Kegg for integration and interpretation of large-scale molecular data sets. Nucleic Acids Res 2011;40:D109-D114.

-22 Takahashi Y, Sawada G, Kurashige J, Uchi R, Matsumura T, Ueo H, Takano Y, Eguchi H, Sudo T, Sugimachi K, Yamamoto H, Doki Y, Mori M, Mimori K: Amplification of pvt-1 is involved in poor prognosis via apoptosis inhibition in colorectal cancers. Br J Cancer 2014;110:164-171.

-23 Wang F, Yuan JH, Wang SB, Yang F, Yuan SX, Ye C, Yang N, Zhou WP, Li WL, Li W, Sun SH: Oncofetal long noncoding rna pvt1 promotes proliferation and stem cell-like property of hepatocellular carcinoma cells by stabilizing nop2. Hepatology 2014;60:1278-1290.

24 Colombo T, Farina L, Macino G, Paci P: Pvt1: A rising star among oncogenic long noncoding rnas. Biomed Res Int 2015;2015:304208.

25 Cui M, You L, Ren X, Zhao W, Liao Q, Zhao Y: Long non-coding rna pvt1 and cancer. Biochem Biophys Res Commun 2016;471:10-14.

26 Chen J, Li Y, Zheng Q, Bao C, He J, Chen B, Lyu D, Zheng B, Xu Y, Long Z, Zhou Y, Zhu H, Wang Y, He X, Shi Y, Huang S: Circular rna profile identifies circpvt1 as a proliferative factor and prognostic marker in gastric cancer. Cancer Lett 2017;388:208-219.

-27 Huang C, Liu S, Wang H, Zhang Z, Yang Q Gao F: Lncrna pvt1 overexpression is a poor prognostic biomarker and regulates migration and invasion in small cell lung cancer. Am J Transl Res 2016;8:5025.

28 Li PD, Hu JL, Ma C, Ma H, Yao J, Chen LL, Chen J, Cheng TT, Yang KY, Wu G: Upregulation of the long noncoding rna pvt1 promotes esophageal squamous cell carcinoma progression by acting as a molecular sponge of mir-203 and lasp1. Oncotarget 2017;8:34164-34176.

29 LIU Y, Quan X, Z, Qin X, M, Lan Y, L: Effect of neoadjuvant chemotherapy on difference of expression of lncrna in ovarian cancer patients. Practical Journal of Cancer 2016;31:384-386.

30 Yuan CL, Li H, Zhu L, Liu Z, Zhou J, Shu Y: Aberrant expression of long noncoding rna pvt1 and its diagnostic and prognostic significance in patients with gastric cancer. Neoplasma 2016;63:442-449.

31 Zhang S, Zhang G, Liu J: Long noncoding rna pvt1 promotes cervical cancer progression through epigenetically silencing mir-200b. APMIS2016;124:649-658.

32 Zhou Q Chen F, Zhao J, Li B, Liang Y, Pan W, Zhang S, Wang X, Zheng D: Long non-coding rna pvt1 promotes osteosarcoma development by acting as a molecular sponge to regulate mir-195. Oncotarget 2016;7

33 Xu MD, Wang Y, Weng W, Wei P, Qi P, Zhang Q, Tan C, Ni SJ, Dong L, Yang Y: A positive feedback loop of Incrna-pvt1 and foxm1 facilitates gastric cancer growth and invasion. Clin Cancer Res 2017;23:2071.

34 Song J, Wu X, Liu F, Li M, Sun Y, Wang Y, Wang C, Zhu K, Jia X, Wang B, Ma X: Long non-coding rna pvt1 promotes glycolysis and tumor progression by regulating mir-497/hk2 axis in osteosarcoma. Biochem Biophys Res Commun 2017

-35 Wang BJ, Ding HW, Ma GA: Long noncoding rna pvt1 promotes melanoma progression via endogenous sponging mir-26b. Oncol Res 2017

-36 Kong R, Zhang EB, Yin DD, You LH, Xu TP, Chen WM, Xia R, Wan L, Sun M, Wang ZX, De W, Zhang ZH: Long noncoding rna pvt1 indicates a poor prognosis of gastric cancer and promotes cell proliferation through epigenetically regulating p15 and p16. Mol Cancer 2015;14:82.

-37 Munafo MR, Flint J: Meta-analysis of genetic association studies. Trends Genet 2004;20:439-444.

-38 Ding J, Li D, Gong, M, Wang J, Wu T, Wang C: Expression and clinical significance of long non-coding rnapvt1 in human gastric cancer. Onco Targets Ther 2015;35:1615-1617.

39 Li Q Dai Y, Wang F, Hou S: Differentially expressed long non-coding rnas and the prognostic potential in colorectal cancer. Neoplasma 2016;63:977.

40 Liu F, Dong Q, Huang J: Overexpression of lncrna pvt1 predicts advanced clinicopathological features and serves as an unfavorable risk factor for survival of patients with gastrointestinal cancers. Cell Physiol Biochem 2017;43:1077-1089.

41 Wu D, Li Y, Zhang H, Hu X: Knockdown of lncrna pvt1 enhances radiosensitivity in non-small cell lung cancer by sponging mir-195. Cell Physiol Biochem 2017;42:2453-2466.

42 Zhuang C, Li J, Liu Y, Chen M, Yuan J, Xing F, Zhan Y, Li L, Lin J, Zhou Q: Tetracycline-inducible shrna targeting long non-coding rna pvt1 inhibits cell growth and induces apoptosis in bladder cancer cells. Oncotarget 2015;6:41194-41203. 


\section{Cellular Physiology Cell Physiol Biochem 2018;46:591-608

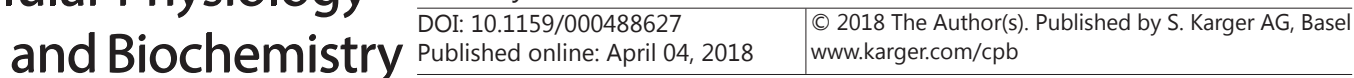

He et al.: Prognostic Significance of PVT1 and Target Gene Network in Cancers

43 Yan C, Chen Y, Kong W, Fu L, Liu Y, Yao Q, Yuan Y: Pvt1-derived mir-1207-5p promotes breast cancer cell growth by targeting stat6. Cancer Sci 2017;108:868-876.

44 Ma Y, Wang P, Xue Y, Qu C, Zheng J, Liu X, Ma J, Liu Y: Pvt1 affects growth of glioma microvascular endothelial cells by negatively regulating mir-186 Tumour Biol 2017;39:1010428317694326.

45 Lan T, Yan X, Li Z, Xu X, Mao Q Ma W, Hong Z, Chen X, Yuan Y: Long non-coding rna pvt1 serves as a competing endogenous rna for mir-186-5p to promote the tumorigenesis and metastasis of hepatocellular carcinoma. Tumour Biol 2017;39:1010428317705338.

46 Schally AV: Hypothalamic hormones: From neuroendocrinology to cancer therapy. Anticancer Drugs 1994;5:115-130.

47 Stanislaus D, Pinter JH, Janovick JA, Conn PM: Mechanisms mediating multiple physiological responses to gonadotropin-releasing hormone. Mol Cell Endocrinol 1998;144:1.

48 Maggi R, Cariboni AM, Marelli MM, Moretti RM, Andrè V, Marzagalli M, Limonta P: Gnrh and gnrh receptors in the pathophysiology of the human female reproductive system. Hum Reprod Update 2016;22:358-381.

49 Millar RP: GnRH II and type II GnRH receptors. Trends Endocrinol Metab 2003;14:35-43.

50 Emons G, Schally AV: The use of luteinizing hormone releasing hormone agonists and antagonists in gynaecological cancers. Hum Reprod 1994;9:1364-1379.

51 Yano T, Pinski J, Radulovic S, Schally AV: Inhibition of human epithelial ovarian cancer cell growth in vitro by agonistic and antagonistic analogues of luteinizing hormone-releasing hormone. Proc Natl Acad Sci U S A 1994;91:1701-1705.

52 Kwok CW, Treeck 0, Buchholz S, Seitz S, Ortmann O, Engel JB: Receptors for luteinizing hormone-releasing hormone (gnrh) as therapeutic targets in triple negative breast cancers (tnbc). Target Oncol 2015;10:365373.

53 Rick FG, Schally AV: Bench-to-bedside development of agonists and antagonists of luteinizing hormonereleasing hormone for treatment of advanced prostate cancer. Urol Oncol 2015;33:270-274.

54 Huang C, Yu W, Wang Q Cui H, Wang Y, Zhang L, Han F, Huang T: Increased expression of the lncrna pvt1 is associated with poor prognosis in pancreatic cancer patients. Minerva Med 2015;106:143.

55 Cui D, Yu CH, Liu M, Xia QQ, Zhang YF, Jiang WL: Long non-coding rna pvt1 as a novel biomarker for diagnosis and prognosis of non-small cell lung cancer. Tumour Biol 2016;37:4127-4134.

56 Ding C, Yang Z, Lv Z, Du C, Xiao H, Peng C, Cheng S, Xie H, Zhou L, Wu J, Zheng S: Long non-coding rna pvt1 is associated with tumor progression and predicts recurrence in hepatocellular carcinoma patients. Oncol Lett 2015;9:955-963.

57 Yang YR, Zang SZ, Zhong CL, Li YX, Zhao SS, Feng XJ: Increased expression of the lncrna pvt1 promotes tumorigenesis in non-small cell lung cancer. Int J Clin Exp Pathol 2014;7:6929. 